NBER WORKING PAPER SERIES

\title{
A QUASI-EXPERIMENTAL ESTIMATE OF THE IMPACT OF FINANCIAL AID ON COLLEGE-GOING
}

\author{
Thomas J. Kane \\ Working Paper 9703 \\ http://www.nber.org/papers/w9703

\section{NATIONAL BUREAU OF ECONOMIC RESEARCH 1050 Massachusetts Avenue} \\ Cambridge, MA 02138 \\ May 2003
}

This research has been supported by the James Irvine Foundation, the William and Flora Hewlett Foundation and the Lumina Foundation. Jeffrey Geppert provided invaluable assistance in assembling the analysis file and in performing the initial impact estimates. Samuel Kipp III, a former executive director of the California Student Aid Commission, provided expert advice and guidance. The current executive director, Walter Boeck, and the staff of the California Student Aid Commission-- particularly Karen Vogel-Henderson and Sarah Tyson-- were extremely patient in answering our many queries. Douglas Staiger and Enrico Moretti, as well as seminar participants at the NBER Higher Education meetings, NBER Summer Institute, UCLA, the California Student Aid Commission, UC-San Diego, University of Chicago and UC-Berkeley provided many insightful suggestions. Matt Wiswall and Rebecca Acosta provided excellent research assistance. The views expressed herein are those of the authors and not necessarily those of the National Bureau of Economic Research.

(C2003 by Thomas J. Kane. All rights reserved. Short sections of text not to exceed two paragraphs, may be quoted without explicit permission provided that full credit including Cnotice, is given to the source. 
A Quasi-Experimental Estimate of the Impact of Financial Aid on College-Going

Thomas J. Kane

NBER Working Paper No. 9703

May 2003

JEL No. I2

\section{$\underline{\text { ABSTRACT }}$}

Although state and federal governments heavily subsidize the price of college, estimates of the impact of these subsidies on college enrollment have not been well-identified. I use a regression discontinuity design to study the impact of the CalGrant program in California on college going. Eligibility requires students to meet minimum thresholds on three characteristics: income, assets and high school Grade Point Average. Because there are several dimensions of eligibility, the analysis allows for specification tests, estimating any discontinuities along a given dimension of eligibility, dependent upon whether one satisfied the other two dimensions of eligibility. The paper uses a novel data collection strategy to measure subsequent college enrollment for 150,000 financial aid applicants in 1998 and 1999. The results suggest large impacts (3 to 4 percentage points) of grant eligibility on college enrollment among financial aid applicants, with larger impacts on the choice of private four-year colleges in California.

Thomas J. Kane

School of Public Policy and Social Research

UCLA, Box 951656

Los Angeles, CA 90095-1656

and NBER

tomkane@ucla.edu 


\section{Introduction}

Government invests large sums in tuition subsidies and student financial aid for college students with the goal of ensuring access to college for high school graduates. The lion's share of such aid comes in the form of direct state appropriations to public post-secondary institutions, which totaled $\$ 63$ billion annually in $2001 .^{1}$ In addition, the federal government provided more than $\$ 8$ billion in means-tested grants to undergraduates during the 2000-01 school year and guaranteed $\$ 37$ billion in student loans (and paying the interest on roughly half of that loan volume while students are in school). ${ }^{2}$ States added $\$ 5$ billion in grant aid to students, much of it means-tested. Given the magnitude of such public investment, empirical researchers have been pre-occupied with estimating the impact of these various subsidies on enrollment decisions, particularly for low-income youth.

However, despite more than three decades of effort, much of the available evidence remains problematic. The primary weakness is that the variation in college price is rarely plausibly exogenous. The main source of variation in price are long-standing differences in states' tuition policy, which are likely to be correlated with other state policies, such as the number of community colleges in a state. Within states, student-level variation in financial aid packages partially reflect differences in academic talent or financial need, which may be only imperfectly measured in observational analyses. Several papers take advantage of large changes in policy, such as the establishment of the federal Pell Grant program in 1973 (Hansen(1983) and

${ }^{1}$ Grapevine: A National Database of Tax Support for Higher Education, Illinois State Univesity, James C. Palmer (ed.).

${ }^{2}$ College Board, Trends in Student Aid, 2001, p. 7. 
Kane(1994)), the termination of tuition benefits for Social Security Survivors in 1982

(Dynarski(Forthcoming)), within-state increases in tuition policy (Kane(1999)) or the establishment of the Hope Scholarship program in Georgia (Dynarski(2000)). However, the results of that literature have often been conflicting. For instance, while the estimates of the impact of the Hope Scholarship program are large, there was no apparent impact on enrollment of low-income youth after the establishment of the Pell Grant program in the mid-Seventies.

In this paper, I exploit several discontinuities in the eligibility formula for the Cal Grant program in California to estimate the impact of financial aid on students' enrollment decisions. In order to be eligible for a Cal Grant A, a student must have achieved a minimum high school GPA, as well as have income and financial assets below specific thresholds. Those who met the GPA and need requirements were eligible for up to $\$ 9400$ per year to attend a private 4-year institution in California (in 1999, \$9036 in 1998). Those choosing to attend the University of California or California State University received a Cal Grant sufficient to cover tuition and required fees. Since the tuition at UC (\$3609 and \$3429 in 1998-99 and 1999-2000 respectively) and at California State University campuses (\$1506 and \$1428 in 1998-99 and 1999-2000 respectively) were considerably lower than $\$ 9400$, eligibility for a Cal Grant A also triggered changes in the relative price of public and private colleges.

For the years I will be studying-- those planning to enter college in the fall of 1998 and 1999-- the GPA thresholds were unknown at the time students were applying. With the number of awards funded by the legislature, the eventual GPA threshold depended upon the number of qualified students applying. The threshold varies from year to year, depending upon the number of applications and the number of available awards. For those applying for the fall of 1996 
through 1999, the GPA threshold for the Cal Grant A took on a range of values-- 3.16, 3.05, 3.15 and 3.09 respectively. The resulting uncertainty surrounding the GPA threshold may have made it difficult for families and students to plan for college, but it was fortuitous for the purpose of evaluation for at least two reasons: First, the students just above and below the threshold might plausibly be expected to have been similar. This would have been less true if the minimum qualifying GPA were announced beforehand, since those most desirous of the financial aid would have been expected to claw their way above the threshold, while those just below the threshold would have contained a disproportionate share of students who did not need the aid. Second, because the GPA threshold was different in the two years we are studying, it allows us to isolate the effect of GPA differences from the effect of the aid itself. (For current cohorts, the GPA threshold is no longer uncertain. Beginning with the class entering in the Fall of 2001, the Cal Grant program was given sufficient funding to guarantee a grant to students with a GPA of 3.00 or higher.)

The source of data for this study is novel. With data provided by the California Student Aid Commission, we began with the universe of California residents submitting federal financial aid applications by the deadline of March 2 in 1998 and 1999. There were roughly 160,000 applicants applying as prospective college freshmen in each of the two years, for a total of roughly 320,000 . Using criteria described in more detail below, I identified a sub-sample of 150,413 students and asked the California Student Aid Commission to obtain information on subsequent college enrollment from the National Student Clearinghouse- a non-profit organization which collects individual student enrollment information from institutions 
comprising 80 percent of 2-year and 4-year college enrollment in the United States. ${ }^{3}$ Therefore, I can estimate the impact of Cal Grant receipt on the subsequent college choices of California financial aid applicants, while controlling for the rich array of family background measures available on the federal financial aid form (including parental education, family composition, income and assets).

In this paper, I study discontinuities in college enrollment at the GPA and income thresholds, using as a control group those who failed to meet one of the other dimensions of eligibility. For example, I study the discontinuity in college enrollment at the GPA threshold for those who met the income and asset requirements, using as a control group those who were not financially eligible. The estimates suggest that eligibility for a Cal Grant A results in a 3 to 4 percentage point rise in the proportion of financial aid applicants enrolling in college in the subsequent year. Moreover, the estimated impact at the GPA threshold is similar to the estimated impact at the income threshold.

\section{Review of Literature on Impact of Tuition Subsidies and Financial Aid}

Over the years, a large literature has developed, studying the impact of various types of tuition and financial aid policies on college-going. In their review of the literature on student responsiveness to changes in college cost, Leslie and Brinkman (1988) report a consensus estimate that a $\$ 1000$ change in college costs $(\$ 2001)$ is associated with a 4 percentage point difference in college enrollment rates. Table 1 summarizes the results from three recent sets of

\footnotetext{
${ }^{3}$ The data I was given had been stripped of name, date of birth and Social Security number, but the remaining data items collected on the Free Application for Federal Student Aid were available to us.
} 
studies, published since the Leslie and Brinkman review: those that use differences in public tuition levels between states and over time, those that evaluate the impact of financial aid policies that operate outside the usual need-analysis system, and those evaluating changes in financial aid policy operating through the regular financial aid process.

The first three papers use between-state differences in state tuition policy and essentially compare the college entry rates of otherwise similar youth in high and low-tuition states. The empirical strategy in this literature typically assumes that the relevant price for marginal students is the tuition at public institutions in their state and evaluates the effect of tuition and collegegoing by comparing college-going rates in high and low-tuition states. Such studies also assume that the supply of college slots is perfectly elastic: given a change in price, it is solely student demand which determines enrollment and not the supply of college slots.

Two characteristics of these studies deserve comment: First, although they use 3 different data sets-- the October Current Population Survey, the National Longitudinal Survey of Youth and the High School and Beyond-- each generates similar results. A \$1000 difference in tuition (\$2001) is associated with a 5 percentage point difference in college-going. Indeed, these estimates are quite consistent with the older literature summarized by Leslie and Brinkman.

Second, a weakness of these studies is that they rely on relatively fixed differences in tuition levels between states. For instance, California has been a relatively low-tuition state for the past forty years. California has also built a number of community colleges around the state. One may be attributing to tuition policy the effect of these other policy differences.

Kane (1994) and Card and Lemieux (2000) include state fixed effects in an analysis using Current Population Survey data and find that the effect of public tuition levels is often not 
statistically significant. Kane(1994) finds a negative and statistically significant effect of tuition on African American youth after including state fixed effects, but the coefficient on tuition is no longer significant for whites with the inclusion of state fixed effects. Card and Lemieux (2000) report small (1 to 2 percentage point difference in college enrollment per $\$ 1000$ difference in tuition) and occasionally statistically insignificant effects of tuition on college going. However, the CPS might not provide the ideal data for testing the effect of tuition, particularly when looking within states. The CPS classifies youth who are temporarily away from home by the state of residence of their parents. College-age youth who have set up their own households will be categorized according to their current state of residence. About twenty percent of college students in the United States attend a college outside of their parents' state of residence. Therefore, the public tuition level in one's current state of residence in the CPS will be an imperfect measure of the price one actually faces and the bias due to this measurement error would be exacerbated by the inclusion of state fixed effects. As a result, Kane (1999) used administrative data to look at what happens to enrollments within a state when it raises tuition. Interestingly, one sees comparable effects of tuition changes within states over time as one would estimate looking across states.

Also cited in Table 1, Sue Dynarski has recently estimated the impact of two important policy changes. One study focused on the impact of the cessation of tuition benefits for Social Security survivors and the other evaluated the effect of the Hope Scholarship program in Georgia. Dynarski (Forthcoming) found that after the discontinuation of the Social Security Student Benefit program, college entry by students with deceased parents declined dramatically, by 19 to 26 percentage points relative to other youth. To convert this estimate to a similar scale 
reported above, Dynarski calculated that the value of the benefit program had been roughly $\$ 6700$ (\$2001). This implies an impact of 3 to 4 percentage points per thousand dollar change in price. Although the change in policy was plausibly exogenous, it is difficult to know whether the responsiveness of such a narrow subgroup-- youth with deceased parents-- can be generalized to other groups. Moreover, the estimate is based upon an exceedingly small sample of 107 children of deceased parents before the change in policy and 49 after the change.

In a second paper, Dynarski studied enrollment rates for youth in Georgia relative to other southern states, before and after the Hope Scholarship program was initiated in that state. She estimates that the program increased college enrollment rates of 18 to 19 -year-olds by 7.0 to 7.9 percentage points. Given the value of the Hope Scholarship, this estimate converts to an estimate of 2 to 3 percentage points per $\$ 1000$ difference in cost.

Despite the above results, the evidence for the impact of the primary federal grant program for low income youth-- the Pell Grant program-- is much weaker. Lee Hansen (1983) first noted that there had been little evidence of a disproportionate rise in college enrollment by low-income youth during the Seventies, when the Pell Grant program was established. Although that paper was criticized for relying too heavily on two years' of data and for including males, whose decisions may have also been affected by the end of the Vietnam War, later work (Kane (1994)) confirmed that the result was not sensitive to the choice of annual end-points or to the inclusion of males. Manski (1993) also reported little evidence of a disproportionate growth in BA completion by low-income youth graduating from high school between 1972 and 1980 . (Despite little evidence of impacts on enrollment of college-age youth, Seftor and Turner (forthcoming, 2002) report evidence of enrollment impacts on older adults.) 
A paper by van der Klaauw (1997) uses an identification strategy most closely related to the one proposed in this paper, but does so to answer a different question. He uses discontinuities in the formula determining fellowship offers at a major eastern university to identify the effect of such offers on the decisions of students to attend that institution. His estimates suggest that each $\$ 1000$ in aid (\$2001) raises the likelihood of attending the university by 3-4 percentage points. A recent paper by Linsenmeier, Rosen and Rouse (2001) also evaluates the impact of one institution's decision to shift its financial aid to low-income students from loans to grants. They find no statistically significant impact on low-income youth in the aggregate, but do find marginally significant results for low-income minorities. However, while such estimates may be useful to individual institutions seeking to calibrate their own financial aid strategy, it is not very useful in attempting to estimate the impact of public subsidies on the proportion of youth choosing to college. Indeed, such own-price elasticities are probably institution-specific, depend upon the policies in place at rival institutions, and may either overstate or understate the effect of public aid on enrollment in the aggregate.

\section{Description of Cal Grant Program}

During the period studied in this paper, the $\mathrm{Cal}$ Grant program provided approximately $\$ 450$ million in aid to undergraduate students annually. Most of that aid was divided between two programs: the Cal Grant A and the Cal Grant B programs. In order to be considered for either type of Cal Grant, a student had to be a resident of California, a U.S. citizen or eligible non-citizen (e.g. permanent resident), not have a BA degree or have defaulted on a prior educational loan and have financial need according to the federal financial aid formula. To 
receive a Cal Grant A (the more generous of the two most common types of Cal Grants), a student was required to have a high school GPA above a specific threshold and income and assets below specific limits. For those applying in 1998 and 1999, the minimum GPA was not known at the time of application- either to applicants or to program administrators- since the cut-off ultimately depended upon the number of eligible applicants. (California law established a fixed number of awards each year. The thresholds were established where the available awards were distributed.) The minimum GPA was established at 3.15 in 1998 and 3.09 in 1999. A student could only use a Cal Grant A to attend a four-year college in California at least half-time. The maximum award for students choosing to attend a private 4-year college was \$9036 and \$9420 in the 1998-99 and 1999-2000 school years respectively. Alternatively, a Cal Grant A could be used to pay full tuition and required fees at a UC or CSU campus. As mentioned above, UC tuition was \$3609 and \$3429 in 1998-99 and 1999-2000 respectively and the CSU tuition was \$1506 and \$1428 in 1998-99 and 1999-2000 respectively. A student meeting the above eligibility requirements for a Cal Grant A could choose to attend a two-year college, but they would be required to put their award on "reserve," which can be done for up to three years.

Students with very low income and assets qualify for Cal Grant B awards. Eligibility for a Cal Grant B is based upon an index using information on income, family size, educational attainment of parents, an indicator for those from single parent families and high school GPA. ${ }^{4}$

${ }^{4}$ In fact, the use of parental education in the Cal Grant B formula is the primary reason for its continuing inclusion on the federal financial aid form, which is meant to serve as the least common denominator for federal and state financial aid programs. Parental education is not directly used in the eligibility for federal financial aid, but will serve as a useful control variable in the present study. 
(Although some high school guidance counselors may be familiar with the way in which the index is calculated, it is not well-documented in the literature that is publicly available.) As with the Cal Grant A, the cut-offs for eligibility depended upon the number of students applying and the number of awards that were authorized by the legislature. As a result, the eventual thresholds were also unknown at the time students were applying.

Because of the more stringent financial eligibility requirements, Cal Grant B recipients tend to come from more disadvantaged households than the Cal Grant A recipients. The median parental income for dependent Cal Grant B recipients was $\$ 14,000$, with a maximum of $\$ 35,000$. In contrast, the median parental income for Cal Grant A recipients was $\$ 31,000$, with a maximum income of $\$ 68,000$. Both programs were restricted to families with assets (excluding home equity) less than $\$ 42,000$.

A majority ( 85 percent) of those who qualify for both programs (the Cal Grant A and the Cal Grant B) choose to use the Cal Grant B. There are two primary reasons for this. First, unlike the Cal Grant A, the Cal Grant B award could be used to attend a community college in California. A student would receive a $\$ 1409$ "subsistence" grant each year to attend a community college under the Cal Grant B and would have to wait to use their Cal Grant A. Moreover, a student can also receive the $\$ 1409$ grant to attend the first year of a 4-year college. But, in the second and subsequent years at a 4-year college, a student would receive the same tuition benefits that were provided Cal Grant A recipients, plus the $\$ 1409$ subsistence grant. Therefore, a student who was planning to attend the University of California in 1998 had a choice between a Cal Grant A, with a present value of 
$\$ 3609+\frac{\$ 3609}{(1+r)}+\frac{\$ 3609}{(1+r)^{2}}+\frac{\$ 3609}{(1+r)^{3}}$ or a Cal Grant B, with a present value

of $\$ 1410+\frac{\$ 3609+\$ 1410}{(1+r)}+\frac{\$ 3609+\$ 1410}{(1+r)^{2}}+\frac{\$ 3609+\$ 1410}{(1+r)^{3}}$. Except for those

with a very high discount rate $(r>.175)$ or plans to remain in a four-year college for only a year or two, the Cal Grant B was likely to be more valuable.

This would not be true at private four-year colleges, since the tuition amounts are much higher. Using a discount rate of 6 percent and a subsistence grant of $\$ 1410$, the Cal Grant A would be worth more than the Cal Grant B if the tuition grant exceeded $\$ 5250$. The mean tuition at private four-year colleges in California in 1998 was $\$ 12,953$ (actually, above the maximum tuition grant available through the Cal Grant A program was $\$ 9,036$ in 1998), meaning that those who are sufficiently low income to qualify for the Cal Grant B program would benefit from Cal Grant A eligibility, if they were to attend a private four-year college in California..

In estimating the impact of crossing the Cal Grant A threshold, I will focus on three different groups: 
C those who are financially ineligible for neither the Cal Grant A nor Cal Grant B

C those who are sufficiently needy to qualify financially for either the Cal Grant A or the Cal Grant B

C those who meet the financial eligibility requirements for the Cal Grant A only, and whose income or assets are too high to qualify for the Cal Grant B.

If the subsidy available through the Cal Grant A has any impact on college going, we would expect to see an impact of crossing the GPA threshold for the second or third group, but not for the first group. Moreover, we might have expected a larger impact for those who were financially eligible for only the Cal Grant A than for those who were poor enough to quality for a Cal Grant B, since most of the latter group will choose to use the Cal Grant B anyway. Finally, we would expect a large impact on the probability of attending a private four-year college among both the second and third groups, since the CalGrant A would greatly lower the relative price of attending a private four-year institution.

\section{Data Description}

The U.S. Department of Education automatically transmits to the California Student Aid Commission (CSAC) all information on family income and resources that are reported on the federal financial aid form (the Free Application for Federal Student Aid (FAFSA)) by California residents. Students are not required to file a separate financial aid application to the state; California residents who submit the federal form by March 2 are considered automatically. The only additional piece of information applicants are required to file is the "Grade Point Average Verification Form", which must be completed by a qualified staff member at each 
applicant's high school. The GPA verification form is relatively short- requesting the student's name, social security number, date of birth and permanent mailing address. The school official is expected to fill in the GPA calculation. The GPA calculation is standardized and many high schools submit high school grade point averages electronically to CSAC. For those who are applying during their senior year in high school, the high school GPA consists of an equally weighted average of all coursework taken during the sophomore and junior year of high school, excluding physical education and ROTC courses. There is no additional weighting for advanced placement courses. Freshman year grades do not count. Moreover, senior year grades do not count unless someone is applying to college for the first time after having graduated from high school. (Interestingly, the GPA weighting formula used by the California Student Aid Commission is different from the GPA weighting formula used by the University of California in its admissions process. As a result, the GPA requirements for admission to the University of California do not map directly onto the CSAC GPA.)

Figure 1 portrays the distribution of high school GPA's for those applying for Cal Grants as first-year college students. Although there is a slightly higher proportion of students with GPA's at the top of the distribution in 1998 than in 1999, the distributions are otherwise similar. The two vertical lines in Figure 1 identify the thresholds used in the two years, 3.15 in 1998 and 3.09 in 1999 . There does not appear to be any significant "clumping" in the distribution of GPA near the respective thresholds.

For most of the paper, we will be identifying the impact of Cal Grant eligibility on the likelihood of college attendance for those with high school GPA's near the respective thresholds. Interestingly, the GPA thresholds in 1998 and 1999 lie well within the range of admission 
standards for all the major segments of postsecondary education in California. Figure 2 reports the distribution of high school GPA (calculated according to the California Student Aid Commission's formula) for those we subsequently observed attending one of the University of California (UC) campuses, one of California State University (CSU) campuses or one of the community colleges (CC) in the state. The vertical lines in Figure 2 depict the 3.09 and 3.15 thresholds. The thresholds lie in the heart of the distributions of GPA's for those who started out at a CSU or community college campus. Moreover, there was a non-negligible portion of those who started at one of the UC campuses with GPA's below the 3.09 and 3.15 threshold (15 percent of UC entrants had high school GPA's below 3.15). ${ }^{5}$

\section{The National Student Clearinghouse Database}

The National Student Clearinghouse is a non-profit organization that maintains enrollment information for roughly 2400 two-year and four-year colleges, comprising 80 percent of total college enrollment in the United States. ${ }^{6}$ The database was originally established to help student loan guarantors and lenders verify enrollment for their borrowers. However, the organization has evolved over time to provide additional services to participating schools, such as helping to satisfy the enrollment reporting requirements for the new education tax credits introduced with the Tax Reform Act of 1997 and allowing colleges to track transfer students.

${ }^{5}$ As noted above, this is partially due to the fact that the GPA used for Cal Grant eligibility is calculated differently from the high school GPA used for University of California admissions.

${ }^{6}$ These rates apply to the 1998-99 time period. The organization now reports to have data for 2700 institutions comprising 91 percent of enrollment. 
The California Student Aid Commission, a partner in this project, was one of the founding members of the National Student Clearinghouse.

Table 2 reports the participation rates of different types of institutions in the NSC database. The first column simply reports the proportion of students in California attending each type of institution. The second column reports the proportion of institutions participating in the database, without weighting by enrollment. When reported simply as a fraction of the total number of institutions, the participation rates are often quite low, with only 55 percent of all institutions nationally participating. However, the non-participants are much smaller institutions on average than participating institutions. The third column reports the participation rates nationally, weighted by enrollment. When weighted by enrollment, the participation rate overall is 80 percent rather than 55 percent. The fourth column reports participation rates for institutions located in California, weighted by their enrollment. Nearly ninety percent of enrollment in California is in participating institutions. Ninety-five percent of public 4-year enrollment and nearly ninety percent of public 2-year enrollment in California is in institutions participating in the database. Private 4-year institutions in CA participate at lower rates (78 percent when weighted by enrollment) and private 2-year institutions are the least likely to participate (34 percent). Fortuitously, as reported in the first column, only 11 percent and 1 percent respectively of enrollment in California institutions attend these categories of institutions. Finally, the last column reports participation rates weighted by the number of California financial aid applicants listing the institution on their federal financial aid form. The participation rate is even higher, 91 percent, and is considerably higher for private 4-year and private 2-year institutions. Apparently, the more selective institutions- with the largest number 
of applications relative to enrollment-- are more likely to participate.

Out of 332,322 applicants for first-year grants over the two years 1998 and 1999, we selected a sample of 150,413 applicants using the following criteria: we took all of those with high school GPA's between 2.50 and 3.60, all those with incomes within $\$ 1500$ of the maximum income limits or with assets within $\$ 2000$ of the asset limits. We also identified a random sample of roughly 5,100 students drawn from the remainder of the GPA, family income and asset distributions. In most of the analysis in this paper, I will focus on the 100 percent sample of those with high school GPA's between 2.50 and 3.60.

The California Student Aid Commission submitted to the National Student Clearinghouse the names, social security numbers and dates of birth of the sample of 150,413 students to verify enrollment. In order to protect the confidentiality of students, we had no direct access to the students' identities. The National Student Loan Clearinghouse matched the student's personal data with their enrollment files and identified up to 11 institutions the sample members were observed attending. The California Student Aid Commission then stripped the students' name, street address and Social Security number before providing us with an analysis file with the enrollment data and all of the data available on the financial aid form. In addition to high school GPA, the file contains a rich array of potential control variables- parental education, detailed income information, detailed asset information, family size and number of other family members in college.

The empirical strategy in this paper will be to explore any discontinuities in college enrollment rates corresponding discontinuities in the eligibility rules-- using the GPA and family income thresholds employed by the Cal Grant A program. Given our choice of sampling frame, 
any estimates will be applicable only to those financial aid applicants with GPA's or family income in the neighborhood of the thresholds. To the extent that the availability of aid may have an effect on the decision by youth and their families to submit a federal financial aid form, we may be understating the impacts for the combined pool of applicants and non-applicants. Moreover, the impact estimates apply to those near the GPA and income margins I am studying. The impact of aid for students with GPA's or income far away from the boundaries may be quite different.

As noted above, not every institution considered by CA financial aid applicants chose to participate in the National Student Clearinghouse data-base. In particular, non-collegiate proprietary institutions and private 2-year and 4-year colleges were less likely to participate. To the extent that receipt of a Cal Grant may lead students to be more likely to attend one of the schools in the database, we may overstate the impact of the program on enrollment rates overall. Alternatively, to the extent that Cal Grant recipients are more likely to attend schools that are not in the database, we may understate the impacts. The net effect is ambiguous a priori. In order to estimate the direction of this bias, we estimate the impacts for the full sample as well as for a subsample for which we are more confident that the NSC data are complete. On the federal financial aid form, students list up to 6 postsecondary institutions where they would like to have their financial aid information sent. (As reported in the Appendix Table 1, only 22 percent of the sample filled out all 6 fields. The remainder of applicants listed less than 6 schools to which they were applying.) In the results below, we also report results for the sample for whom all of the schools listed on the FAFSA (up to 6 schools are listed) are also included in the NSC database. 
We limit the analysis to (1) dependent students, (2) who were 17 to 20 in the year of their application, (3) who had not attended any institution prior to June of the year in which they were applying and (4) who listed at least one institution participating in the NSC database on the FAFSA form. Moreover, we focus on the sample with GPA's from 2.50 to 3.60 - in the neighborhood of the GPA thresholds for GPA eligibility. These restrictions reduce the sample to 59,581. Of these students, roughly two-thirds had full coverage of the institutions they listed on their FAFSA in the NSLC. Even though the likelihood that any one institution participated in the sample was roughly 90 percent, a large share of the sample listed at least one institution among the 6 that they listed on the FAFSA. Table 3 reports the mean characteristics of the whole sample, as well as for the subsample with full NSC coverage. Average incomes were slightly higher for the sample with full NSC coverage $-\$ 52,477$ versus $\$ 50,212$ for those without full coverage. Moreover, parental education was also slightly higher for the subsample with full NSC coverage. As a result of these differences in family characteristics and the ambiguous direction of the bias due to institutional non-participation, we will report the impacts both for the subsample with full NSC coverage as well as for the full sample.

Table 4 reports the proportion of students meeting the eligibility requirements receiving Cal Grants. Between 80 and 89 percent of those who were estimated to be eligible for an award received funding from the Cal Grant program if they decided to enroll in college. The remainder may have enrolled in college less than half time, enrolled in an institution that was not eligible to participate in the program (such as an out-of-state college) or may have been subsequently identified to have been ineligible.

Figure 3 reports the proportion of college entrants receiving Cal Grant A's and B's in 
1998 and 1999. The figures were calculated by one-hundredth of a high school GPA point and were reported separately for those who were financially eligible for either a $\mathrm{Cal}$ Grant $\mathrm{A}$ or a $\mathrm{Cal}$ Grant B and those who were financially eligible for a Cal Grant A only. At 3.15 in 1998 and 3.09 in 1999, there was a sharp increase in the proportion of youth receiving a Cal Grant A, particularly among those who were eligible for a Cal Grant A only. Among those who were sufficiently low income to qualify for a Cal Grant B, there was a modest increase in Cal Grant A receipt among those with GPA sufficiently high to qualify. Most of these low-income students receiving Cal Grant A's were attending private four-year colleges.

\section{Using Discontinuities in GPA}

Table 5 reports the proportion of students entering college by eligibility category (financially eligible for A or B, financially eligible for A only and financially ineligible for both), by high school GPA category and by year. The top panel of results apply to 1998, when the threshold was 3.15. Among those who were financially eligible for Cal Grant A, those with GPA's between 3.15 and 3.17 were roughly 5.5 percentage points more likely to enter college in the subsequent year than those with GPA's between 3.12 and 3.14. By comparison, among those who were financially ineligible for both programs, those with the slightly higher GPA's were 3.8 percentage points less likely to enroll. The difference-in-the-difference, reported in the last column of Table 5, would imply a 9.3 percentage point impact on college-going of receipt of a Cal Grant A, relative to no financial aid. (The difference is statistically significant at the .05 level.)

In 1999, the GPA threshold for Cal Grant A eligibility was 3.09. Again, the point 
estimates suggest a larger jump in college enrollment rates at the threshold for those who were financially eligible for a Cal Grant A than for those who were financially eligible for neither (as reported in the difference-in-difference column, the difference-in-differences was 3.7 percentage points), but this difference was not statistically significant at the traditional levels.

The estimates in Table 5 also suggest that the very low-income students, who were eligible for a Cal Grant B regardless of their GPA's, also experienced a jump in enrollment at the 3.15 GPA threshold for receipt of a Cal Grant B. The difference-in-differences relative to the financially ineligible was 8.3 percentage points. This is somewhat puzzling, given the fact that most of those who qualify for either a Cal Grant A or a Cal Grant B, choose a B. In fact, the results including a polynomial in GPA and a wider GPA range reported below do not show an impact of receiving an A grant for those financially eligible for a B grant. Moreover, for those who were sufficiently low income to qualify for a B grant, there is no evidence of an impact of receiving an A in 1999.

Table 5 also allows one to study the effect of being above and below the 1998 threshold in 1999 and vice versa-- the off-year effects of being above each year's threshold. If the differences noted above reflect program impacts and not some non-linearity in the relationship between high school GPA and college-going, then we would not expect to see any apparent differences-in-differences for the various groups at the thresholds in the off years. In fact, none of the point estimates of off-year differences are large or statistically significant.

\section{$\underline{\text { Results Using a Polynomial in GPA }}$}

Suppose y is a latent variable determining the likelihood of attending college. Financial 
aid applicants enter college if $y>0$ in the following specification:

$$
\begin{aligned}
& y=f(g p a)+d \alpha+Z \beta+\varepsilon \\
& \text { where } \mathrm{d}=1 \text { if gpa } \geq \text { gpa }_{\mathrm{o}}
\end{aligned}
$$

where gpa is high school grade point average, gpa $_{0}$ represents the threshold for eligibility, $\mathrm{Z}$ represents over covariates (such as family income and assets) and $\mathrm{f}($.$) is a polynomial function of$ GPA. As discussed by others, such as Hahn, Todd and van der Klaauw (2001), the key identifying assumption is that, in the absence of the Cal Grant program, college going would be a continuous function of high school GPA. Moreover, conditional on $\mathrm{f}(\mathrm{gpa}), \mathrm{d}$ is assumed to be uncorrelated with unmeasured determinants of college-going. In the case where $\varepsilon$ is distributed normally, the above can be estimated with a probit specification and the impact measured as $\mathrm{P}\left(\mathrm{y}>0 \mid \mathrm{gpa}=\mathrm{gpa}_{\mathrm{o}}, Z=\bar{Z}, \mathrm{~d}=1\right)-\mathrm{P}\left(\mathrm{y}>0 \mid \mathrm{gpa}=\mathrm{gpa}_{\mathrm{o}}, Z=\bar{Z}, \mathrm{~d}=0\right)$. I estimate the same specification separately for the three different subgroups discussed above- very low income and asset youth eligible for either the Cal Grant A or B, moderate income and asset youth who are eligible for a Cal Grant A only and higher income or asset youth who are financially eligible for neither. This formulation allows for two natural specification tests. First, one can test whether $\alpha=0$ for the third group who were financially ineligible for Cal Grants. This is only testable since there is more than one dimension along which eligibility is determined. Second, I will test whether the inclusion of other covariates, Z, has an impact on the impact estimate-- that is whether $\mathrm{P}\left(\mathrm{y}>0 \mid \mathrm{gpa}=\mathrm{gpa}_{\mathrm{o}} \mathrm{d}=1\right)-\mathrm{P}\left(\mathrm{y}>0 \mid \mathrm{gpa}=\mathrm{gpa}_{\mathrm{o}} \mathrm{d}=0\right)$ estimated with only the polynomial in GPA is equal to $\mathrm{P}\left(\mathrm{y}>0 \mid \mathrm{gpa}=\mathrm{gpa}_{\mathrm{o}}, Z=\bar{Z}, \mathrm{~d}=1\right)-\mathrm{P}\left(\mathrm{y}>0 \mid \mathrm{gpa}=\mathrm{gpa}_{\mathrm{o}}, Z=\bar{Z}, \mathrm{~d}=0\right)$, estimated with other covariates, $\mathrm{Z}$, included. This is a test of whether the indicator for eligibility (d) is correlated with other 
characteristics conditional on $\mathrm{f}(\mathrm{gpa})$. Moreover, for $\mathrm{f}(\mathrm{gpa})$, I report results using polynomials of various orders.

Using a probit specification, Table 6 reports the marginal impact of having a GPA at or above the Cal Grant threshold in 1998 and 1999 on the probability of attending college in the subsequent year, including a cubic polynomial in GPA (as will be shown below, the results are not sensitive to the choice of polynomials quadratic and above). The results are reported for 1998 and 1999 separately, with and without including other covariates (other than the polynomial in GPA), for the full sample and for the subsample of applicants for whom all their college choices were included in the NSC database, and for the three financial eligibility categories. (All marginal impacts were calculated using the mean characteristics of those across the three financial eligibility categories.)

There are five findings worth noting in Table 6: First, the results suggest statistically significant increases in college enrollment at the GPA thresholds in 1998 for those who were financially eligible for the Cal Grant A. For the subsample with full NSC coverage of their college choices, the difference in college going immediately above and below the GPA threshold was roughly 4.2 percentage points for those financially eligible for only the Cal Grant A. The estimated impact for those sufficiently poor to qualify for the Cal Grant B was only .008 and was statistically indistinguishable from zero. (This is consistent with the finding that those who qualify for either the Cal Grant A or Cal Grant B overwhelmingly choose the latter.) Second, among those who were financially ineligible for both programs, there was no difference in college enrollment at the threshold in any of the specifications. Third, in 1998, the point estimates are larger for the subsample of youth with full NSC coverage than for the sample with 
any NSC coverage-- 4.2 percentage points rather than 2.9 percentage points.

Fourth, in none of the specifications did the addition of covariates lead to substantive changes in the results. Other regressors included dummies for mother's education, father's education, family size, an indicator for whether there were others in the household planning to attend college next year, an indicator for whether or not the family reported zero assets and the $\log$ of family income. The similarity of the results with and without covariates suggests that the dummy indicator for being above the GPA threshold is not picking up some discontinuity in background characteristics at the GPA threshold. (In a similar spirit, I also tested for discontinuities in other prior application behavior, such as the probability of applying to the University of California or applying to a private four-year college in California at the GPA threshold. There were no discontinuities in either behavior at the GPA threshold for any of the subgroups.)

Finally, as reported on the second page of Table 6, the impacts which were statistically significant in 1998 were generally not statistically significant in 1999. Although there is no single explanation for the differing results, there are several possible explanations. First, the job market in California was stronger in 1999 than in 1998. Between June 1998 and June 1999, unemployment in California fell from 5.9 percent to 5.2 percent overall and from 19.1 to 17.8 percent among 16-19 year olds. That was essentially the peak of the labor market in California, with unemployment rates falling only to 5.1 percent in the subsequent June before rising. With opportunity costs higher and-- for those with liquidity constraints-- good prospects for finding part-time employment to help pay for college, students may simply have been less price sensitive. Second, for those with GPA's on the margin, the final award letters were sent out 
much earlier in 1999 than they had been in 1998. Final award letters notifying youth of eligiblity for a Cal Grant A were sent in August in 1998 and in June in 1999. The earlier notification in 1999 may have allowed institutions to more readily adjust their own aid awards to offset the value of Cal Grants received by eligible students. Indeed, there is some evidence reported below that there was a discontinuity in college-going for University of California applicants for whom there was not complete crowd-out, even in 1999.

Figures 4 and 5 summarize graphically the results from specifications (1), (3) and (5) for the subsample with full NSC coverage as well as for the full sample. The solid line in each of the graphs represents the predicted enrollment rates implied by the probit specifications. We divided the sample into groups in categories of three-one-hundredths of a GPA point. The dotted line represents the actual enrollment rates for these groups of students.

The above specifications simply tested whether there was a statistically significant discontinuity in enrollment rates at the actual GPA thresholds. However, in order to rule out spurious relationships generated by mis-specification, I also ask whether the actual thresholds "fits" the data better than other nearby thresholds. In other words, we would like to estimate the optimal location of any break in the relationship, not simply to ask whether one could identify a break where the program rules suggest one would expect to find one.

To do so, I re-estimated the probit specifications in columns (2) and (4) for the full sample in 1998, using a range of different GPA thresholds, between 3.00 and 3.25 at intervals of .01. The differences in the log likelihood for each specification relative to the minimum log likelihood across all specifications are reported in Figures 6 and 7 for the sample with full NSC coverage and the full sample respectively. For those who were financially eligible for the Cal 
Grant A, there is a clear "spike" in the log likelihood at 3.15, which corresponds with the eligibility threshold used in that year. Since Figure 6 is reported as the difference in log likelihood relative to the maximum, the horizontal lines drawn at -1.35 and at -1.90 allow one to calculate the 90 and 95 percent confidence interval around the optimal choice of threshold. ${ }^{7}$ For those who were financially eligible for a Cal Grant A, the 90 percent confidence interval for the spike would include 3.15 through 3.17 . The 95 percent confidence interval would include 3.13 through 3.17. There is no clear spike in the log likelihood for those who were eligible for a Cal Grant B.

Table 7 explores the use of alternative specifications of the polynomial in GPA. We only report the results for those financially eligible for either type of Cal Grant and those financially eligible for a Cal Grant A in 1998. The specifications start with a quadratic in GPA and include successively higher order polynomials. The effect of crossing the GPA threshold is .028 and only marginally statistically significant for the full sample with full NSC coverage and not statistically significant for the full sample in the quadratic specifications. However, the similarity of the results in columns (2) through (5) indicate that the results are quite robust to the inclusion of cubic and higher order polynomials in GPA.

Table 8 explores subgroup impacts in 1998 for those who were financially eligible for only the Cal Grant A. The table reports threshold impacts for model specifications estimated separately by whether or not the family reported any financial assets (home equity is not

${ }^{7}$ The likelihood ratio test would require us to multiply the difference by 2 . Since the critical value for a $\chi^{2}$ distribution with 1 degree of freedom is 2.71 and 3.84 at the .10 and .05 level respectively, the 90 and 95 percent confidence intervals would include estimates with differences less than 1.35 and 1.92 respectively. 
included), whether there were other family members enrolled in college, parental education and gender. The only statistically significant difference was for those with other family members in college. On the one hand, one might expect those with other family members in college to have stronger preferences for schooling and lower price elasticities. On the other hand, those with other family members in college may be more liquidity constrained. Among those who were financially eligible for the Cal Grant A, receiving a Cal Grant A had a larger impact for those who had other family members in college. The results suggest that the latter effect may dominate.

\section{Using Discontinuities in Income and Assets}

The preceding analysis relied upon the discontinuities in the high school GPA requirements for identification. One advantage of the high school GPA requirement is that the thresholds were unknown at the time of application. However, there are other thresholds in the formula- specific income limits, for instance- which could be used for identification, as long as parents and students are only vaguely aware of where those thresholds lie. Because the income information is supposed to be drawn from parent's 1040 tax forms, we are not concerned that families misrepresent their income on the form, but that those who meet the income threshold are simply more likely to apply.

One test of the precision of people's awareness of the thresholds is to study the distribution of income around the thresholds and look for any spikes in the distribution near the thresholds. Unfortunately, the program thresholds often correspond with round numbers (for example, the income limit for a family of size 4 was $\$ 59,000$ in 1999) and, looking at one year 
alone, it is impossible to distinguish strategic responses from simple rounding by respondents. Fortunately, the thresholds change from year to year, so it is possible to investigate whether changes in the thresholds correspond with changes in the pattern of reporting. The program imposes separate income thresholds for families of different sizes-- for families of 3 or fewer, 4 , 5 or 6 and more. In 1998, the thresholds were $\$ 53,100, \$ 57,500, \$ 61,900$ and $\$ 67,000$ respectively; in 1999 , the thresholds were $\$ 54,500, \$ 59,000, \$ 63,500$ and $\$ 68,700$. Figure 8 reports the distribution of family income in the range from $\$ 40,000$ to $\$ 80,000$ for dependent students who are both GPA and asset eligible for a Cal Grant A. Although there does appear to be some clumping in the distribution of income, the nature of the bunching of responses does not appear to be sensitive to changes in the income thresholds from year to year.

Table 9 reports the marginal impacts on the likelihood of enrolling in college of having income above the threshold for eligibility for a Cal Grant A. As above, the estimates are reported for the subsample with full NSC coverage as well as for the full sample. Moreover, the estimates are reported separately for those who meet both the asset and GPA test for eligibility and for those that fail to meet one of those eligibility criteria. If any difference in college enrollment is due to Cal Grant eligibility, then there should be no discontinuity at the income threshold for those who fail to meet one of the other eligibility criteria.

When pooling the data for 1998 and 1999, among those meeting both the asset and GPA tests, those who had incomes immediately above the thresholds were 4.2 percentage points less likely to enroll in college in the subsequent year. Column (2) provides a specification test by testing the same relationship for those failing one of the other criteria. There is no apparent effect of having income above the income threshold for those failing one of the other eligibility 
criteria.

Figure 9 summarizes the results from specifications (1) and (2) in Table 9 for the sample with full NSC coverage. We calculated mean enrollment rates in \$3000 intervals according to their distance from the income thresholds. (Because different family sizes use different thresholds, we first took the difference from the respective threshold and include dummies for family size in each specification.) The figures also contain plots of "predicted" enrollment rates. (Note that because the equations included other regressors, the predicted line is not a "smooth" function of income differences alone.)

As we did with the GPA eligibility rules, we also compared the use of alternative income thresholds. We re-estimated the probit specifications in Table 9, trying alternative thresholds in $\$ 1000$ intervals from $\$ 20,000$ below the actual threshold to $\$ 20,000$ above the actual threshold. We did so for those who were GPA and asset eligible (for whom we might have expected a discontinuity) as well as for those who were either GPA or asset ineligible (for whom there should have been no discontinuity in enrollment rates at the income threshold). The results are reported in Figure 10. For the potentially eligible group, the data strongly prefer a threshold in the neighborhood of 0 , although the most preferred threshold is actually $\$ 2000$ above the actual threshold. For those who were ineligible for due to their GPA or assets, there is no apparent threshold in the neighborhood near zero.

\section{Asset Thresholds}

In addition to maximum income and minimum GPA thresholds, dependent Cal Grant recipients cannot have certain assets worth more than $\$ 42,000$. (Relevant assets include, cash, 
savings accounts, checking accounts, mutual funds, trust funds, Education IRA's, the equity value of real estate other than one's primary residence, business and farm equity. The equity value of primary residences, value of life insurance, pre-paid tuition plans, retirement IRA's, pension funds and annuities are excluded.) Figure 11 portrays the distribution of relevant assets for dependent students. One might expect those with substantial financial resources to be less price sensitive. In results not included in this paper, I failed to find evidence of any discontinuity in college enrollment above and below the asset threshold. However, as reported in Figure 11, there were few students near the asset threshold (only 9 percent of dependent students had relevant assets above the threshold and only 3 percent of the sample had assets within $\$ 10,000$ on either side of the threshold), meaning that there was relatively little power in the test.

\section{Impacts on Choice of Institution}

The Cal Grant A provides very different award amounts, depending upon the institution students attend. For instance, in 1999, a student would receive $\$ 9420$ to attend a private 4-year institution in California and $\$ 3429$ to attend the University of California. The Cal Grant program not only subsidized college enrollment, but reduced by roughly $\$ 6000$ the relative cost of attending a private institution. In this section, I evaluate the evidence on the impact of the program on students choice of institution using the data for 1998.

To do so, I first limited the sample to those who listed at least one private four-year California institution among the institutions they listed on the federal financial aid form. I then studied any discontinuities in the probability of attending a private four-year California 
institution at both the GPA and income thresholds. The results are reported in Table 10. As reported in the top panel of Table 10, the lowest income youth (who were financially eligible for a B or an A type grant) were 20 percentage points more likely to attend a private institution in the state if they were Cal Grant eligible. Recall that for those attending the University of California, most students would choose the B grant over the A grant if they qualified for either. By taking the B grant, they forego the tuition benefit for the first year in return for receiving an additional $\$ 1410$ per year for four years. When tuition is only $\$ 3400$, this is a worthwhile tradeoff for students attending the University of California unless a student has a very high discount rate. However, when the tuition benefit is worth $\$ 9400$ per year, the promise of $\$ 1410$ for 4 years is not worth it. So the Cal Grant A eligibility is worth something, even for the low income students who would qualify for a Cal Grant B if they miss the GPA threshold. The point estimate is also positive for those who were financially eligible only for the Cal Grant A, but not statistically significant at traditional levels. $(t=1.4)$ The discontinuity at the GPA threshold is neither large nor statistically significant for those who were financially ineligible. Figure 12 reports the actual and predicted private 4-year enrollment rates by GPA for those applying to at least one private 4-year college in California, using the results from the top panel of Table 10 .

The bottom panel of Table 10 reports the discontinuities at the income threshold for those who were otherwise eligible and for those who missed either the GPA or the asset cutoff. There was a 24 percentage point difference in the likelihood of attending a private four-year college immediately above and below the income threshold. In other words, given the magnitude of the grants offered to those attending private institutions in the state, Cal Grant eligibility seemed to 
have a large impact on students' choice of type of institution.

Are the Extra Price Subsidies for Private College Cost Effective?

The rationale for the larger subsidies for private college enrollment is to divert a portion of students to private four-year colleges in California, at a time when the University of California is facing capacity constraints. Given the large anticipated increase in the size of the college-age population over the next 15 years, the state has already planned to open a new campus at Merced and to expand enrollments at many of the other campuses in the system. Whether or not the extra subsidies actually save the state money depends upon the magnitude of the impact on enrollment, the proportion of youth who would have attended private colleges anyway and the marginal cost of a new slot at the University of California. The marginal cost of an additional slot at the University of California, although unknown, may be quite high. If I assume that the marginal impacts of Cal Grant receipt on the decision to attend a private four-year college in California is the same for anyone with GPA above the threshold, that the availability of the aid does not affect the decision to apply to a private four-year college and that all of the new entrants were drawn from the University of California (rather than attending a college out of state), I estimate that the marginal cost of the slot at the University of California would have to be above $\$ 15,195$ for the additional subsidy for private college entrants to make sense. ${ }^{8}$ This is only

\footnotetext{
${ }^{8}$ In 1998, the difference in the Cal Grant awarded to those attending a private four-year college in California rather than the University of California was $\$ 5427$ (\$9036-\$3609). If $\delta$ represents the increment in the probability of attending a private four year college and if e represents the private college enrollment rate without subsidies, then the subsidy would have to be above $\frac{(e+\delta) 5427}{\delta}$. For $\delta$, I used the proportion of eligible students falling into each
} 
slightly larger than the average cost per student at the University of California.

\section{Impact per Dollar of Net Aid}

Without knowing more about the extent to which Cal Grants "crowd out" other forms of institutional aid, it is only possible to construct an lower bound estimate of the effect of net aid on students' college enrollment decisions, using the gross amounts of aid awarded as part of the Cal Grant program. ${ }^{9}$ For instance, the median value of the Cal Grant A award for dependent students (who were eligible for the Cal Grant A only, with GPA's in the interval 3.09 and 3.15)

was $\$ 3609$. If we were to divide the 4.2 percentage point estimate in Table 6 by $\$ 3609$, it would yield an estimate of 1.2 percentage point difference in college enrollment for every $\$ 1000$ difference in price. That is considerably smaller than the estimates from the literature summarized above.

However, given that there is likely to be some crowd-out, that is likely to understate the impact per dollar of net aid received. In order to estimate the magnitude of the crowd-out, one needs information on the aid decisions of institutions themselves. This is difficult to obtain from private institutions, particularly since financial aid officers often have the discretion to award grant aid for reasons not directly related to the federal need formula. However, at the University of California, as well as at California State University campuses, the lion's share of

category to calculate the weighted average of the impact for those eligible for Cal Grant A's $(.361 * .204+(1-.361) * .064)$. For e, I used the proportion of eligible four-year private college applicants actually attending a private four-year college (.322).

${ }^{9}$ Given program maxima, there was no crowding out of federal Pell Grant dollars. However, for some students, there may have been some crowding out of federal loan amounts. 
university grant aid is awarded on the basis of a simple formula.

At the University of California, the university starts with a budget amount for each student, based upon tuition, required fees and students' housing choices. For example, the budget amount at the University of California at Berkeley in 1998 for a student planning to live off-campus was $\$ 13,363 .{ }^{10}$ From this budget amount, the university would subtract a uniform “self-help" amount for each student (\$6100 and \$6300 in 1998 and 1999 respectively) as well as the "expected family contribution" from the federal formula as well as any other grant aid the student received. The two primary sources of non-institutional grant aid were the federal Pell program and the Cal Grant program. In determining their university grant award, a student would receive the maximum of the above difference and 0 . For students with very low expected family contributions, one-hundred percent of any Cal Grant received would be crowded out by reductions in institutional aid. For example, a student with an expected family contribution of 0 would have received $\$ 3000$ from the Pell Grant program in 1998. Using the budget amount above for UC-Berkeley students living off campus, the student would have received $\max (13,363-6100-3000-0,0)=\$ 4263$ in university grant aid if they did not receive a Cal Grant or $\max (13,363-6100-3000-3609,0)=\$ 654$ if they did receive a Cal Grant A of $\$ 3609$. For students with higher EFC's, there would be less crowd-out. Although the formula at the California State University was different, there would have been considerable crowd-out there as well.

For the graphs in Figure 13, I used the formula for institutional grants at the University of California and at the California State University to estimate the amount of grant aid students

\footnotetext{
${ }^{10}$ This was the budget amount for UC Berkeley in the Cal Grant records. The actual budget amount at UC Berkeley may have differed slightly.
} 
would receive with and without the Cal Grant A, by expected family contribution. When the two lines depicting grant aid with and without a Cal Grant A correspond for those with low "expected family contributions", there is one-hundred percent crowd out. For those with moderal expected family contributions (approximately between $\$ 4000$ and $\$ 8000$ at the University of California and between $\$ 1000$ and $\$ 4000$ at the California State University) there is partial crowd-out. There is a range with zero crowd out (approximately between $\$ 8000$ and $\$ 9000$ at the University of California and between $\$ 4000$ and $\$ 7000$ at the California State University). For those with higher expected family contributions, there is no crowd-out, since youth would not be eligible for any Cal Grant.

For those who were financially eligible for the Cal Grant A, I re-estimated the impact of Cal Grant A eligibility, separately for those for whom the above calculations would have implied 100 percent crowd-out and less than 100 percent crowd-out. I also limited the sample to those who had applied to UC or to CSU. In all but one case, the point estimates were larger for those for whom there was less than 100 percent crowd-out, although the differences were generally not statistically significant. Interestingly, despite the failure to find impacts in 1999 for the pooled sample, there seemed to be large and statistically significant impacts in 1999 for those applying to the University of California, for whom the crowd-out was less than 100 percent.

Using the above formulae for institutional grant aid, I calculated the mean increase in net aid for someone with a high school GPA of 3.15 in 1998. For those who were financially eligible for a Cal Grant A, the average increase in net aid resulting from Cal Grant A eligibility was $\$ 418$ at the University of California and $\$ 493$ at California State University. Using the 4.2 point estimate from Table 6 in the numerator and the average of $\$ 418$ and $\$ 493$ in the 
denominator would imply an impact of 9.2 percentage point difference in college-going per $\$ 1000$ different in net price, which would be on the high end of the literature.

\section{Conclusion}

Given the size of the public investment devoted to subsidizing the price of higher education, the quality of the evidence on the impact of price subsidies is surprisingly weak. The evidence on the impact of means-tested grant programs has been particularly ambiguous. There was no disproportionate rise in enrollment by low-income youth following the establishment of the Pell Grant program in the mid-Seventies (Hansen (1983) and Kane(1994)). Beyond the magnitude of public dollars at stake, there is another reason to redouble efforts to estimate the impact of means-tested financial aid programs. Since the labor market payoff to college began rising in the late Seventies, college enrollment rates have risen substantially. In 1980, 25 percent of 18-24 year-olds were enrolled in college. By October 2000, 36 percent of 18-24 yearolds were enrolled in college. As college enrollment rates have risen, so too has the cost of broad-based subsidies to keep tuition low at public institutions. Although broad-based subsidies have the advantage of transparency and do not impose additional taxes on income and savings such as those implicit in means-tested financial aid formulae (Feldstein(1995), Dick and Edlin (1997)), they are also harder to sustain as an increasingly large fraction of the population takes the government up on its generous offer. Moreover, the size of the college-age cohorts, which declined in size by nearly 20 percent between 1980 and 1995 has turned around and is expected to rise by roughly the same amount in the coming 10 years.

The most consistent evidence of price impacts has been drawn from programs that 
operate outside the federal need analysis system-- such as tuition policy, or the Hope Scholarship program in Georgia or the termination of tuition benefits for Social Security survivors. Given the complexities of the financial aid programs, one hypothesis to account for the failure to find an effect of means-tested programs is that students only learn about the amount of means-tested aid available to them quite late in the process- after they have submitted their financial aid forms and college applications. If the financial aid process is sufficiently opaque, perhaps only those who are committed to going to college expend the effort to find out how much grant aid they may receive. Such complexity may limit the impact of policies which target by family income, rather than provide large across-the-board subsidies. The above results are intended to identify the impact of additional dollars on students' enrollment decisions, among those who have already gone through the process of applying for college and financial aid.

The results suggest that additional financial aid dollars have a large impact on students' decisions even when provided late in the process. Financial aid applicants were 3 to 4 percentage points more likely to enroll in college as a result of the receipt of a Cal Grant A award, even after they have already made the investment of filing a federal financial aid form and applied to college. In future work with these data, we hope to study the effect on eventual college enrollment rates- not just focusing on enrollment in the one year following application. Moreover, we hope to learn more about the impact of aid availability on the choice of different types of colleges and on the length of time students remain in college. With the addition of Social Security earnings records, the study would provide a means for estimating the effect of educational attainment on earnings for those who were on the margin of deciding whether or not to go to college. 


\section{References:}

Cameron, Stephen V; Heckman, James J. "Life Cycle Schooling and Dynamic Selection Bias: Models and Evidence for Five Cohorts of American Males" Journal of Political Economy. Vol. 106 (2). p 262-333. April 1998

Card, David and Thomas Lemieux "Dropout and Enrollment Trends in the Post-War Period: What Went Wrong in the 1970's" NBER Working Paper 7658, April, 2000.

Dick, Andrew and Aaron Edlin "The Implicit Taxes from College Financial Aid" Journal of Public Economics (1997) Vol. 65, No. 3, pp. 295-322.

Dynarski, Susan. "Hope for Whom? Financial Aid for the Middle Class and Its Impact on College Attendance" National Bureau of Economic Research Working Paper 7756, June 2000 .

Dynarski, Susan. "Does Aid Matter? Measuring the Effect of Student Aid on College Attendance and Completion" American Economic Review (Forthcoming).

Feldstein, Martin. "College Scholarship Rules and Private Saving" American Economic Review (1995) Vol. 85, pp. 552-566.

Hahn, Jinyong, Petra Todd and Wilbert Van der Klaauw, "Identification and Estimation of Treatment Effects with a Regression Discontinuity Design" Econometrica (2001) Vol. 69, pp. 201-209.

Hansen, W. Lee "Impact of Student Financial Aid on Access" in Joseph Froomkin (ed.) The Crisis in Higher Education (New York: Academy of Political Science, 1983).

Kane, Thomas J. "College Attendance By Blacks Since 1970: The Role of College Cost, Family Background and the Returns to Education" Journal of Political Economy (1994) Vol. 102, No. 5, pp. 878-911.

Kane, Thomas J. The Price of Admission: Rethinking How Americans Pay for College (Washington, DC: Brookings Institution and Russell Sage, 1999).

Linsenmeier, David M., Harvey Rosen and Cecilia Rouse "Financial Aid Packages and College Enrollment Decisions: An Econometric Case Study" Princeton University Industrial Relations Section Working Paper No. 459, November 2001.

Seftor, Neil S. and Sarah E. Turner, "Back to School: Federal Student Aid Policy and Adult College Enrollment" Journal of Human Resources (forthcoming)

van der Klaauw, Wilbert. "A Regression-Discontinuity Evaluation of the Effect of Financial Aid Offers on College Enrollment" New York University Department of Economics mimeo, 
March 1997. (Revised April, 2001) Forthcoming in the International Economic Review under the title "Estimating the Effect of Financial Aid Offers on College Enrollment: A Regression-Discontinuity Approach" 
Table 1. Estimated Impact of a $\$ 1000$ Change in Direct Cost of College on College Entry Rates College (per \$1000 2001)

\begin{tabular}{|c|c|c|}
\hline Study: & Estimate: & Brief Description: \\
\hline \multicolumn{3}{|c|}{ Literature Before 1987: } \\
\hline $\begin{array}{l}\text { Leslie and Brinkman } \\
\text { (1987) }\end{array}$ & $\begin{array}{l}-.04 \\
(.004)\end{array}$ & Literature review of 25 articles \\
\hline \multicolumn{3}{|c|}{ Based on Between-State Differences in Tuition: } \\
\hline $\begin{array}{l}\text { Cameron and Heckman } \\
\text { (1999) }\end{array}$ & $\begin{array}{l}-.06 \\
(.02)\end{array}$ & $\begin{array}{l}\text { State differences in public tuition } \\
\text { charges. (NLSY) }\end{array}$ \\
\hline $\begin{array}{l}\text { Kane } \\
(1994)\end{array}$ & $\begin{array}{l}-.04 \\
(.01)\end{array}$ & $\begin{array}{l}\text { State differences in public tuition charges. } \\
\text { (October CPS) }\end{array}$ \\
\hline $\begin{array}{l}\text { Kane } \\
(1999)\end{array}$ & $\begin{array}{l}-.04 \\
(.01)\end{array}$ & $\begin{array}{l}\text { State differences in public tuition } \\
\text { charges. (NELS) }\end{array}$ \\
\hline \multicolumn{3}{|c|}{ Based On Non-Traditional Financial Aid: } \\
\hline $\begin{array}{l}\text { Dynarski } \\
(1999)\end{array}$ & $\begin{array}{l}-.04 \\
(.02)\end{array}$ & $\begin{array}{l}\text { End of Social Security Student Benefit } \\
\text { Program }\end{array}$ \\
\hline $\begin{array}{l}\text { Dynarski } \\
(2000)\end{array}$ & $\begin{array}{l}-.03 \\
(.02)\end{array}$ & Hope Scholarship Program in Georgia \\
\hline \multicolumn{3}{|c|}{ Before-After the Pell Program was Established in 1973: } \\
\hline $\begin{array}{l}\text { Hansen } \\
(1983)\end{array}$ & & $\begin{array}{l}\text { No disproportionate growth by } \\
\text { low-income. (Oct. CPS) }\end{array}$ \\
\hline $\begin{array}{l}\text { Kane } \\
(1994)\end{array}$ & & $\begin{array}{l}\text { No disproportionate growth by low- } \\
\text { income. (Oct. CPS) }\end{array}$ \\
\hline $\begin{array}{l}\text { Manski } \\
(1993)\end{array}$ & & $\begin{array}{l}\text { No disproportionate growth in BA } \\
\text { Completion by Low-Income } \\
\text { (NLS-72 and HSB) }\end{array}$ \\
\hline
\end{tabular}


Table 2.

Participation Rates in the National Student Clearinghouse

\begin{tabular}{|c|c|c|c|c|c|}
\hline & $\begin{array}{c}\% \text { of } \\
\text { CA } \\
\text { Students } \\
\text { Attending }\end{array}$ & $\begin{array}{c}\text { National } \\
\text { Unweighted }\end{array}$ & $\begin{array}{c}\text { National } \\
\text { Weighted } \\
\text { by } \\
\text { Enrollment }\end{array}$ & $\begin{array}{c}\text { California } \\
\text { Weighted } \\
\text { by } \\
\text { Enrollment }\end{array}$ & $\begin{array}{c}\text { National } \\
\text { Weighted } \\
\text { by } \\
\text { California } \\
\text { FAFSA } \\
\text { Applicants }\end{array}$ \\
\hline Public 4-Year & 25 & .77 & .87 & .95 & .95 \\
\hline Private 4-Year & 11 & .52 & .77 & .78 & .85 \\
\hline Public 2-Year & 63 & .60 & .77 & .89 & .88 \\
\hline Private 2-Year & 1 & .21 & .38 & .33 & .90 \\
\hline Total: & 100 & .55 & .80 & .89 & .91 \\
\hline
\end{tabular}

Note: The percentage of CA students attending each type of institution was calculated using the proportion of college students attending each type of institution in CA. 
Table 3. Characteristics by Extent of NSC Coverage of FAFSA Colleges

\begin{tabular}{|l|c|c|c|}
\hline $\begin{array}{l}\text { Standard Deviations in } \\
\text { Parentheses for Continuous Var.) }\end{array}$ & $\begin{array}{c}\text { Sample } \\
\text { with } 1^{\text {st }} \text { School } \\
\text { Included }\end{array}$ & $\begin{array}{c}\text { Full NSC } \\
\text { Coverage }\end{array}$ & $\begin{array}{c}\text { Incomplete NSC } \\
\text { Coverage }\end{array}$ \\
\hline Percent of Full Sample & 100 & .637 & .363 \\
Dependent Family Income & $\$ 51,656$ & $\$ 52,477$ & $\$ 50,212$ \\
Family Size & $(47,765)$ & $(47,461)$ & $(48,260)$ \\
Prop. w/ Oth Fam Memb in Coll & 4.33 & 4.31 & 4.35 \\
Prop. with GPA\$3.09 & .351 & $(1.47)$ & $(1.49)$ \\
GPA & .594 & .356 & .342 \\
Assets>0 & 3.15 & .596 & .590 \\
Net Worth if $>0$ & $(.30)$ & 3.15 & 3.14 \\
(Excludes Housing) & .654 & $.30)$ & $.30)$ \\
Mother's Highest: \#Jr. High & $\$ 48,157$ & $\$ 46,605$ & .628 \\
High School & $(150,473)$ & $(139,590)$ & $(167,042)$ \\
College & .130 & .118 & .151 \\
Unknown & .362 & .366 & .354 \\
Father's Highest: \#Jr. High & .416 & .425 & .402 \\
High School & .321 & .091 & .093 \\
College & .441 & .109 & .141 \\
Unknown & .118 & .114 & .313 \\
\hline Sample Size & 59,581 & 37,977 & .422 \\
\hline
\end{tabular}

Note: Estimated for those who were dependents, with no prior college enrollment spells, aged 18 to 20 and with high school GPA's between 2.50 and 3.60. The sample was limited to those for whom the first school listed on the FAFSA was included in the NSC. 
Table 4. Proportion of Eligible Students Receiving Awards

\begin{tabular}{|c|c|c|c|}
\hline & $\begin{array}{c}\text { Financially } \\
\text { Elig for } \\
\text { A or B }\end{array}$ & $\begin{array}{c}\text { Financially } \\
\text { Elig for } \\
\text { A Only }\end{array}$ & $\begin{array}{c}\text { Financially } \\
\text { Ineligible }\end{array}$ \\
\hline With 2.50\#GPA\#Threshold & & & \\
\hline P(Enrolling in College) & .835 & .837 & .859 \\
P(Cal Grant A or B|Enrolling in College) & .824 & .001 & .030 \\
P(Cal Grant A|Enrolling in College) & .000 & .000 & .000 \\
P(Cal Grant B|Enrolling in College) & .824 & .001 & .030 \\
\hline With Threshold\#GPA\#3.60 & & & .901 \\
P(Enrolling in College) & .874 & .891 & .015 \\
P(Cal Grant A or B|Enrolling in College) & .891 & .814 & .000 \\
P(Cal Grant A|Enrolling in College $)$ & .091 & .814 & .015 \\
P(Cal Grant B|Enrolling in College $)$ & .800 & .000 & \\
\hline
\end{tabular}

Note: The above were estimated for dependent students, aged 17-20, with their first choice from the FAFSA included in the NSC database. 
Table 5. Difference-in-Difference Estimates of the Impact of Cal Grant Eligibility on College Enrollment 1998: GPA Threshold of 3.15

\begin{tabular}{|c|c|c|c|c|c|}
\hline \multirow[b]{2}{*}{ GPA Range } & \multirow[b]{2}{*}{$\begin{array}{c}\text { Fin. Eligible } \\
\text { for A or B } \\
\text { (1) }\end{array}$} & \multirow[b]{2}{*}{$\begin{array}{l}\text { Fin. Eligible } \\
\text { for A Only } \\
\text { (2) }\end{array}$} & \multirow[b]{2}{*}{$\begin{array}{l}\text { Fin. Eligible } \\
\text { for Neither } \\
\text { (3) }\end{array}$} & \multicolumn{2}{|c|}{ Difference-in-Difference } \\
\hline & & & & $\begin{array}{c}\text { Incremental } \\
\text { Effect of A } \\
\text { Above B } \\
(1)-(3) \\
\end{array}$ & $\begin{array}{c}\text { Incremental } \\
\text { Effect of } \\
\text { A Only } \\
(2)-(3) \\
\end{array}$ \\
\hline $3.06-3.08$ & $\begin{array}{c}.858 \\
(.021)\end{array}$ & $\begin{array}{c}.849 \\
(.014)\end{array}$ & $\begin{array}{c}.864 \\
(.013)\end{array}$ & & \\
\hline $3.09-3.11$ & $\begin{array}{c}.833 \\
(.029)\end{array}$ & $\begin{array}{c}.845 \\
(.020)\end{array}$ & $\begin{array}{c}.871 \\
(.019)\end{array}$ & $\begin{array}{l}-.032 \\
(.042)\end{array}$ & $\begin{array}{c}-.011 \\
(.033)\end{array}$ \\
\hline $3.12-3.14$ & $\begin{array}{c}.831 \\
(.027)\end{array}$ & $\begin{array}{c}.824 \\
(.019)\end{array}$ & $\begin{array}{c}.876 \\
(.017)\end{array}$ & & \\
\hline $3.15-3.17$ & $\begin{array}{c}.876 \\
(.019) \\
\end{array}$ & $\begin{array}{c}.879 \\
(.013) \\
\end{array}$ & $\begin{array}{c}.838 \\
(.015) \\
\end{array}$ & $\begin{array}{c}.083 \\
(.040) \\
\end{array}$ & $\begin{array}{c}.093 \\
(.032) \\
\end{array}$ \\
\hline \multicolumn{6}{|c|}{ 1999: GPA Threshold of 3.09} \\
\hline \multirow[b]{2}{*}{ GPA Range } & \multirow[b]{2}{*}{$\begin{array}{c}\text { Fin. Eligible } \\
\text { for A or B } \\
\text { (1) }\end{array}$} & \multirow[b]{2}{*}{$\begin{array}{c}\text { Fin. Eligible } \\
\text { for A Only } \\
\text { (2) }\end{array}$} & \multirow[b]{2}{*}{$\begin{array}{l}\text { Fin. Eligible } \\
\text { for Neither } \\
\text { (3) }\end{array}$} & \multicolumn{2}{|c|}{ Difference-in-Difference } \\
\hline & & & & $\begin{array}{c}\text { Incremental } \\
\text { Effect of A } \\
\text { Above B } \\
(1)-(3) \\
\end{array}$ & $\begin{array}{c}\text { Incremental } \\
\text { Effect of } \\
\text { A Only } \\
(2)-(3) \\
\end{array}$ \\
\hline $3.06-3.08$ & $\begin{array}{c}.825 \\
(.018)\end{array}$ & $\begin{array}{c}.840 \\
(.014)\end{array}$ & $\begin{array}{c}.903 \\
(.011)\end{array}$ & & \\
\hline $3.09-3.11$ & $\begin{array}{c}.831 \\
(.025)\end{array}$ & $\begin{array}{c}.875 \\
(.017)\end{array}$ & $\begin{array}{c}.901 \\
(.017)\end{array}$ & $\begin{array}{c}.008 \\
(.037)\end{array}$ & $\begin{array}{c}.037 \\
(.030)\end{array}$ \\
\hline $3.12-3.14$ & $\begin{array}{c}.872 \\
(.019)\end{array}$ & $\begin{array}{c}.860 \\
(.017)\end{array}$ & $\begin{array}{c}.894 \\
(.015)\end{array}$ & & \\
\hline $3.15-3.17$ & $\begin{array}{c}.866 \\
(.017)\end{array}$ & $\begin{array}{c}.874 \\
(.013)\end{array}$ & $\begin{array}{c}.892 \\
(.012)\end{array}$ & $\begin{array}{l}-.004 \\
(.032)\end{array}$ & $\begin{array}{c}.016 \\
(.029)\end{array}$ \\
\hline
\end{tabular}

Note: Estimated for dependent applicants, aged 17 to 20, for the subsample with full NSC coverage. 
Table 6. Marginal Impacts of Crossing Calgrant GPA Threshold on College Going in the Subsequent Year: 1998

\begin{tabular}{|c|c|c|c|c|c|c|}
\hline & \multicolumn{2}{|c|}{$\begin{array}{l}\text { Fin. Eligible } \\
\text { for A Only }\end{array}$} & \multicolumn{2}{|c|}{$\begin{array}{l}\text { Fin. Eligible } \\
\text { for B or A }\end{array}$} & \multicolumn{2}{|c|}{$\begin{array}{l}\text { Fin. Eligible } \\
\text { for Neither }\end{array}$} \\
\hline & $(1)$ & (2) & $(3)$ & (4) & $(5)$ & $(6)$ \\
\hline & \multicolumn{6}{|c|}{ Subsample with Full NSC Coverage } \\
\hline GPA $\$ 315$ & $\begin{array}{l}.042 \\
(.017)\end{array}$ & $\begin{array}{l}.042 \\
(.017)\end{array}$ & $\begin{array}{l}.008 \\
(.026)\end{array}$ & $\begin{array}{l}.013 \\
(.033)\end{array}$ & $\begin{array}{l}-.008 \\
(.016)\end{array}$ & $\begin{array}{l}-.011 \\
(.018)\end{array}$ \\
\hline \multirow[t]{2}{*}{ Sample Size } & \multicolumn{2}{|c|}{7,269} & \multicolumn{2}{|c|}{3,151} & \multicolumn{2}{|c|}{7,438} \\
\hline & \multicolumn{6}{|c|}{ Full Sample } \\
\hline GPA $\$ 315$ & $\begin{array}{l}.029 \\
(.015)\end{array}$ & $\begin{array}{c}.032 \\
(.016)\end{array}$ & $\begin{array}{l}.027 \\
(.023)\end{array}$ & $\begin{array}{l}.031 \\
(.026)\end{array}$ & $\begin{array}{c}-.014 \\
(.015)\end{array}$ & $\begin{array}{l}-.019 \\
(.018)\end{array}$ \\
\hline Sample Size & \multicolumn{2}{|c|}{11,750} & \multicolumn{2}{|c|}{5,461} & \multicolumn{2}{|c|}{11,600} \\
\hline $\begin{array}{l}\text { Order of Polynomial } \\
\text { in GPA? }\end{array}$ & 3 & 3 & 3 & 3 & 3 & 3 \\
\hline Covariates Included? & No & Yes & No & Yes & No & Yes \\
\hline
\end{tabular}

Note: The sample was limited to dependent students, aged 17-20, who had not been enrolled in college previously, and whose first choice school was included in the NSC. The above represent marginal impacts on probability of college enrollment in year following Cal Grant application, evaluated at the mean characteristics of those in the sample. All specifications also included GPA, GPA ${ }^{2}, \mathrm{GPA}^{3}$. Other covariates included an indicator of whether there were others in the household planning to be in college, dummies for family size, mother's education, father's education, an indicator of whether the family had zero assets and family income. 
Table 6. Marginal Impacts of Crossing Calgrant GPA Threshold on College Going in the Subsequent Year: 1999 (Continued)

\begin{tabular}{|c|c|c|c|c|c|c|}
\hline & \multicolumn{2}{|c|}{$\begin{array}{l}\text { Fin. Eligible } \\
\text { for A Only }\end{array}$} & \multicolumn{2}{|c|}{$\begin{array}{l}\text { Fin. Eligible } \\
\text { for B or A }\end{array}$} & \multicolumn{2}{|c|}{$\begin{array}{l}\text { Fin. Eligible } \\
\text { for Neither }\end{array}$} \\
\hline & $(1)$ & (2) & $(3)$ & (4) & $(5)$ & $(6)$ \\
\hline & \multicolumn{6}{|c|}{ Subsample with Full NSC Coverage } \\
\hline GPA $\$ 309$ & $\begin{array}{l}.005 \\
(.015)\end{array}$ & $\begin{array}{l}.005 \\
(.016)\end{array}$ & $\begin{array}{l}.004 \\
(.005)\end{array}$ & $\begin{array}{l}.004 \\
(.006)\end{array}$ & $\begin{array}{l}-.002 \\
(.029)\end{array}$ & $\begin{array}{l}.001 \\
(.025)\end{array}$ \\
\hline \multirow[t]{2}{*}{ Sample Size } & \multicolumn{2}{|c|}{7,423} & \multicolumn{2}{|c|}{4,773} & \multicolumn{2}{|c|}{7,923} \\
\hline & \multicolumn{6}{|c|}{ Full Sample } \\
\hline GPA\$309 & $\begin{array}{l}.013 \\
(.014)\end{array}$ & $\begin{array}{l}.013 \\
(.014)\end{array}$ & $\begin{array}{l}.004 \\
(.004)\end{array}$ & $\begin{array}{l}.004 \\
(.004)\end{array}$ & $\begin{array}{l}-.018 \\
(.031)\end{array}$ & $\begin{array}{l}-.018 \\
(.031)\end{array}$ \\
\hline Sample Size & \multicolumn{2}{|c|}{11,620} & \multicolumn{2}{|c|}{7,402} & \multicolumn{2}{|c|}{11,748} \\
\hline $\begin{array}{l}\text { Order of Polynomial } \\
\text { in GPA? }\end{array}$ & 3 & 3 & 3 & 3 & 3 & 3 \\
\hline Covariates Included? & No & Yes & No & Yes & No & Yes \\
\hline
\end{tabular}

Note: The sample was limited to dependent students, aged 17-20, who had not been enrolled in college previously, and whose first choice school was included in the NSC. The above represent marginal impacts on probability of college enrollment in year following Cal Grant application, evaluated at the mean characteristics of those in the sample. All specifications also included GPA, GPA ${ }^{2}, \mathrm{GPA}^{3}$. Other covariates included an indicator of whether there were others in the household planning to be in college, dummies for family size, mother's education, father's education, an indicator of whether the family had zero assets and family income. 


\section{Table 7.}

Varying the Order of the Polynomial in GPA

\begin{tabular}{|c|c|c|c|c|c|}
\hline & (1) & $(2)$ & $(3)$ & $(4)$ & $(5)$ \\
\hline & \multicolumn{5}{|c|}{ Financially Eligible for A Only } \\
\hline & \multicolumn{5}{|c|}{ 1998: Subsample with Full NSC Coverage } \\
\hline GPA $\$ 315$ & $\begin{array}{l}.028 \\
(.014)\end{array}$ & $\begin{array}{c}.042 \\
(.017)\end{array}$ & $\begin{array}{l}.042 \\
(.017)\end{array}$ & $\begin{array}{l}.041 \\
(.019)\end{array}$ & $\begin{array}{l}.042 \\
(.018)\end{array}$ \\
\hline \multirow[t]{2}{*}{ Sample Size } & \multicolumn{5}{|c|}{7,269} \\
\hline & \multicolumn{5}{|c|}{ 1998: Full Sample } \\
\hline GPA\$315 & $\begin{array}{l}.015 \\
(.013)\end{array}$ & $\begin{array}{c}.032 \\
(.016)\end{array}$ & $\begin{array}{l}.033 \\
(.016)\end{array}$ & $\begin{array}{l}.035 \\
(.017)\end{array}$ & $\begin{array}{l}.035 \\
(.017)\end{array}$ \\
\hline \multirow[t]{3}{*}{ Sample Size } & \multicolumn{5}{|c|}{11,750} \\
\hline & \multicolumn{5}{|c|}{ Financially Eligible for A or B } \\
\hline & \multicolumn{5}{|c|}{ 1998: Subsample with Full NSC Coverage } \\
\hline GPA\$315 & $\begin{array}{l}-.007 \\
(.026)\end{array}$ & $\begin{array}{c}.013 \\
(.033)\end{array}$ & $\begin{array}{l}.013 \\
(.033)\end{array}$ & $\begin{array}{l}.001 \\
(.036)\end{array}$ & $\begin{array}{l}.002 \\
(.035)\end{array}$ \\
\hline \multirow[t]{2}{*}{ Sample Size } & \multicolumn{5}{|c|}{3,151} \\
\hline & \multicolumn{5}{|c|}{ 1998: Full Sample } \\
\hline GPA $\$ 315$ & $\begin{array}{l}.011 \\
(.020)\end{array}$ & $\begin{array}{c}.031 \\
(.026)\end{array}$ & $\begin{array}{l}.031 \\
(.026)\end{array}$ & $\begin{array}{l}.027 \\
(.027)\end{array}$ & $\begin{array}{l}.027 \\
(.027)\end{array}$ \\
\hline Sample Size & \multicolumn{5}{|c|}{5,461} \\
\hline $\begin{array}{l}\text { Order of Polynomial } \\
\text { in GPA? }\end{array}$ & 2 & 3 & 4 & 5 & 6 \\
\hline Covariates Included? & Yes & Yes & Yes & Yes & Yes \\
\hline
\end{tabular}

Note: The sample was limited to dependent students, aged 17-20, who had not been enrolled in college previously, and whose first choice school was included in the NSC. The above represent marginal impacts on probability of college enrollment in year following Cal Grant application, evaluated at the mean characteristics of those in the sample. All specifications also included GPA, GPA ${ }^{2}, \mathrm{GPA}^{3}$. Other covariates included an indicator of whether there were others in the household planning to be in college, dummies for family size, mother's education, father's education, an indicator of whether the family had zero assets and family income. 
Table 8. Subgroup Impacts in 1998

\begin{tabular}{|c|c|c|c|}
\hline & \multicolumn{3}{|c|}{$\begin{array}{l}\text { Financially Eligible } \\
\text { for A Only }\end{array}$} \\
\hline & $(1)$ & $(2)$ & Diff. \\
\hline & Zero Assets & Assets $>20,000$ & \\
\hline \multirow[t]{2}{*}{ GPA\$315 } & $\begin{array}{l}.032 \\
(.029)\end{array}$ & $\begin{array}{l}.025 \\
(.032)\end{array}$ & $\begin{array}{l}-.007 \\
(.043)\end{array}$ \\
\hline & $\begin{array}{l}\text { No Other Fam } \\
\text { In College }\end{array}$ & $\begin{array}{c}\text { Other } \\
\text { Fam in Coll }\end{array}$ & \\
\hline \multirow[t]{2}{*}{ GPA\$315 } & $\begin{array}{l}.015 \\
(.020)\end{array}$ & $\begin{array}{l}.082 \\
(.026)\end{array}$ & $\begin{array}{l}.067 \\
(.033)\end{array}$ \\
\hline & $\begin{array}{c}\text { No Coll } \\
\text { Educ Parents }\end{array}$ & $\begin{array}{c}2 \text { Coll } \\
\text { Educ Parents }\end{array}$ & \\
\hline \multirow[t]{2}{*}{ GPA $\$ 315$} & $\begin{array}{l}.040 \\
(.025)\end{array}$ & $\begin{array}{l}.032 \\
(.026)\end{array}$ & $\begin{array}{l}-.008 \\
(.036)\end{array}$ \\
\hline & Females & Males & \\
\hline GPA $\$ 315$ & $\begin{array}{l}.001 \\
(.023)\end{array}$ & $\begin{array}{l}.054 \\
(.025)\end{array}$ & $\begin{array}{l}.053 \\
(.034)\end{array}$ \\
\hline
\end{tabular}

Note: Each of the specifications above were estimated separately, with a cubic in GPA and the other covariates described in Table 4. The sample was limited to dependent students, aged 17-20, who had not been enrolled in college previously and for whom all schools listed on the FAFSA were included in the National Student Clearinghouse.. The above represent marginal impacts on probability of college enrollment in year following Cal Grant application, evaluated at the mean characteristics of those in the sample. 


\section{Table 9. Marginal Impacts of Crossing Cal Grant Income Threshold on College Going in the Subsequent Year}

\begin{tabular}{||l|cc|}
\hline \multirow{1}{*}{} & \multicolumn{2}{|c|}{ Pooling } \\
& \multicolumn{2}{|c|}{ 1998 and 1999 } \\
\cline { 2 - 3 } & $\begin{array}{c}\text { GPA\& } \\
\text { Asset } \\
\text { Eligible }\end{array}$ & $\begin{array}{c}\text { GPA or } \\
\text { Asset } \\
\text { Ineligible }\end{array}$ \\
\hline \hline & $(1)$ & $(2)$ \\
\hline Income Below & Subsample with Full NSC Coverage \\
Threshold & 042 & -.022 \\
Sample Size & $(.020)$ & $(.012)$ \\
\hline & 5,558 & 6,901 \\
\hline Income Below & \multicolumn{2}{|c|}{ Full Sample } \\
Threshold & .031 & -.010 \\
Sample Size & $(.018)$ & $(.013)$ \\
\hline Order of Polynomial & 8,410 & 10,266 \\
\hline in Income? & 4 & Yes \\
\hline Covariates Included? & Yes & \\
\hline
\end{tabular}

Note: The sample was limited to dependent students, aged 17-20, who had not been enrolled in college previously, who had GPA's between 2.50 and 3.60 and who had family income within $\$ 20,000$ above or below the income threshold. The above represent marginal impacts on probability of college enrollment in year following Cal Grant application, evaluated at the mean characteristics of those in the sample. All specifications also included GPA, GPA ${ }^{2}$. Other covariates included an indicator of whether there were others in the household planning to be in college, dummies for family size, mother's education, father's education, an indicator of whether the family had zero assets and family income for dependent students. 
Table 10.

Marginal Impacts of Cal Grant A Eligibility on Probability of Attending a
Private 4-Year College In California in 1998

\author{
At GPA Threshold
}

\begin{tabular}{||l|c|c|c|}
\hline \hline & $\begin{array}{c}\text { Fin. Eligible } \\
\text { for B or A } \\
(1)\end{array}$ & $\begin{array}{c}\text { Fin. Eligible } \\
\text { for A Only } \\
(2)\end{array}$ & $\begin{array}{c}\text { Fin. Eligible } \\
\text { for Neither } \\
(3)\end{array}$ \\
\hline \hline GPA\$315 & .204 & .064 & -.033 \\
Sample Size & $(.095)$ & $(.047)$ & $(.051)$ \\
& 524 & 1855 & 2243 \\
\hline
\end{tabular}

Note: The sample was limited to dependent students, aged 17-20, who had not been enrolled in college previously, with full NSC coverage who listed at least one private 4-year CA institution on the FAFSA form. The above represent marginal impacts on probability of attending a private 4-year college in California, evaluated at the mean characteristics of those in the sample. All specifications also included GPA, GPA ${ }^{2}, \mathrm{GPA}^{3}$. Other covariates included an indicator of whether there were others in the household planning to be in college, dummies for family size, mother's education, father's education, an indicator of whether the family had zero assets and family income.

\title{
At Income Threshold
}

\begin{tabular}{||l|c|c|}
\hline & $\begin{array}{c}\text { GPA and } \\
\text { Asset Eligible } \\
(1)\end{array}$ & $\begin{array}{c}\text { GPA or } \\
\text { Asset Ineligible }\end{array}$ \\
\hline \hline Income Below & .241 & $(2)$ \\
Threshold & $(.090)$ & .021 \\
Sample Size & 836 & $(.073)$ \\
\hline
\end{tabular}

Note: The sample was limited to dependent students, aged 17-20, who had not been enrolled in college previously, who had GPA's between 2.50 and 3.60 and who had family income within $\$ 20,000$ above or below the income threshold. The above represent marginal impacts on probability of college enrollment in year following Cal Grant application, evaluated at the mean characteristics of those in the sample. All specifications also included GPA, GPA ${ }^{2}$. Other covariates included an indicator of whether there were others in the household planning to be in college, dummies for family size, mother's education, father's education, an indicator of whether the family had zero assets and family income for dependent students. 
Table 11.

\section{Estimated Impact of GPA Threshold on College Going Rates Imputing Net Aid using UC and CSU Financial Aid Rules}

\begin{tabular}{|l|c|c|}
\hline $\begin{array}{l}\text { Estimated for those who were } \\
\text { Financially Eligible for } \\
\text { Cal Grant A and Not B }\end{array}$ & $\begin{array}{c}\text { Estimated Net Aid } \\
=0\end{array}$ & $\begin{array}{c}\text { Estimated Net Aid } \\
>0\end{array}$ \\
\hline 1998: & & .071 \\
Applicants to & .042 & $(.054)$ \\
University of California & $(.030)$ & .059 \\
\hline $\begin{array}{l}\text { Applicants to } \\
\text { California State University }\end{array}$ & .026 & $(.026)$ \\
\hline 1999: & $(.032)$ & .129 \\
Applicants to & -.027 & $(.082)$ \\
University of California & $(.028)$ & -.010 \\
\hline Applicants to & .001 & $(.025)$ \\
California State University & $(.032)$ & \\
\hline
\end{tabular}

Note: The net value of a Cal Grant A award was calculated using the financial aid rules described in the text. Mean impacts were estimated using the means for 1998. Specification was otherwise the same as in column (2) of Table 6. 
Appendix Table 1.

Number of Schools Listed on FAFSA Form by Cal Grant Applicants

\begin{tabular}{|l|c|}
\hline & Percent of Students: \\
\hline 1 & 21 \\
\hline 2 & 15 \\
\hline 3 & 15 \\
\hline 4 & 14 \\
\hline 5 & 12 \\
\hline 6 & 22 \\
\hline Total & $100 \%$ \\
\hline & Average $=3.4$ \\
\hline
\end{tabular}


Appendix Table 2.

Proportion of Those Applying to a Private 4-Year College in California Attending Such Institutions

1998: GPA Threshold of 3.15

\begin{tabular}{|c|c|c|c|c|c|}
\hline \multirow[b]{2}{*}{ GPA Range } & \multirow[b]{2}{*}{$\begin{array}{c}\text { Fin. Eligible } \\
\text { for A or B } \\
\text { (1) }\end{array}$} & \multirow[b]{2}{*}{$\begin{array}{l}\text { Fin. Eligible } \\
\text { for A Only } \\
\text { (2) }\end{array}$} & \multirow[b]{2}{*}{$\begin{array}{l}\text { Fin. Eligible } \\
\text { for Neither } \\
\text { (3) }\end{array}$} & \multicolumn{2}{|c|}{ Difference-in-Difference } \\
\hline & & & & $\begin{array}{c}\text { Incremental } \\
\text { Effect of A } \\
\text { Above B } \\
(1)-(3) \\
\end{array}$ & $\begin{array}{c}\text { Incremental } \\
\text { Effect of } \\
\text { A Only } \\
(2)-(3) \\
\end{array}$ \\
\hline $2.50-2.94$ & $\begin{array}{c}.222 \\
(.046) \\
81\end{array}$ & $\begin{array}{c}.296 \\
(.022) \\
442\end{array}$ & $\begin{array}{c}.321 \\
(.024) \\
371\end{array}$ & & \\
\hline $2.95-3.04$ & $\begin{array}{c}.174 \\
(.057) \\
45\end{array}$ & $\begin{array}{c}.276 \\
(.032) \\
192\end{array}$ & $\begin{array}{c}.321 \\
(.034) \\
193\end{array}$ & & \\
\hline $3.05-3.14$ & $\begin{array}{c}.150 \\
(.056) \\
40\end{array}$ & $\begin{array}{c}.345 \\
(.035) \\
184\end{array}$ & $\begin{array}{c}.392 \\
(.034) \\
204\end{array}$ & & \\
\hline $3.15-3.24$ & $\begin{array}{c}.369 \\
(.060) \\
65\end{array}$ & $\begin{array}{c}.390 \\
(.035) \\
195\end{array}$ & $\begin{array}{c}.381 \\
(.032) \\
226\end{array}$ & $\begin{array}{c}.230 \\
(.096)\end{array}$ & $\begin{array}{c}.059 \\
(.068)\end{array}$ \\
\hline $3.25-3.34$ & $\begin{array}{c}.226 \\
(.053) \\
62\end{array}$ & $\begin{array}{c}.437 \\
(.035) \\
206\end{array}$ & $\begin{array}{c}.317 \\
(.027) \\
293\end{array}$ & & \\
\hline $3.35-3.44$ & $\begin{array}{c}.345 \\
(.052) \\
85\end{array}$ & $\begin{array}{c}.467 \\
(.033) \\
227\end{array}$ & $\begin{array}{c}.346 \\
(.025) \\
350\end{array}$ & & \\
\hline $3.45-3.60$ & $\begin{array}{c}.376 \\
(.039) \\
154\end{array}$ & $\begin{array}{c}.507 \\
(.024) \\
444\end{array}$ & $\begin{array}{c}.276 \\
(.018) \\
626\end{array}$ & & \\
\hline
\end{tabular}

Note: Limited to dependent, 17-20 year olds, with full NSC coverage, who requested on FAFSA that financial aid information be sent to at least one private 4-year college in California. 
Figure 1.

1998

1999

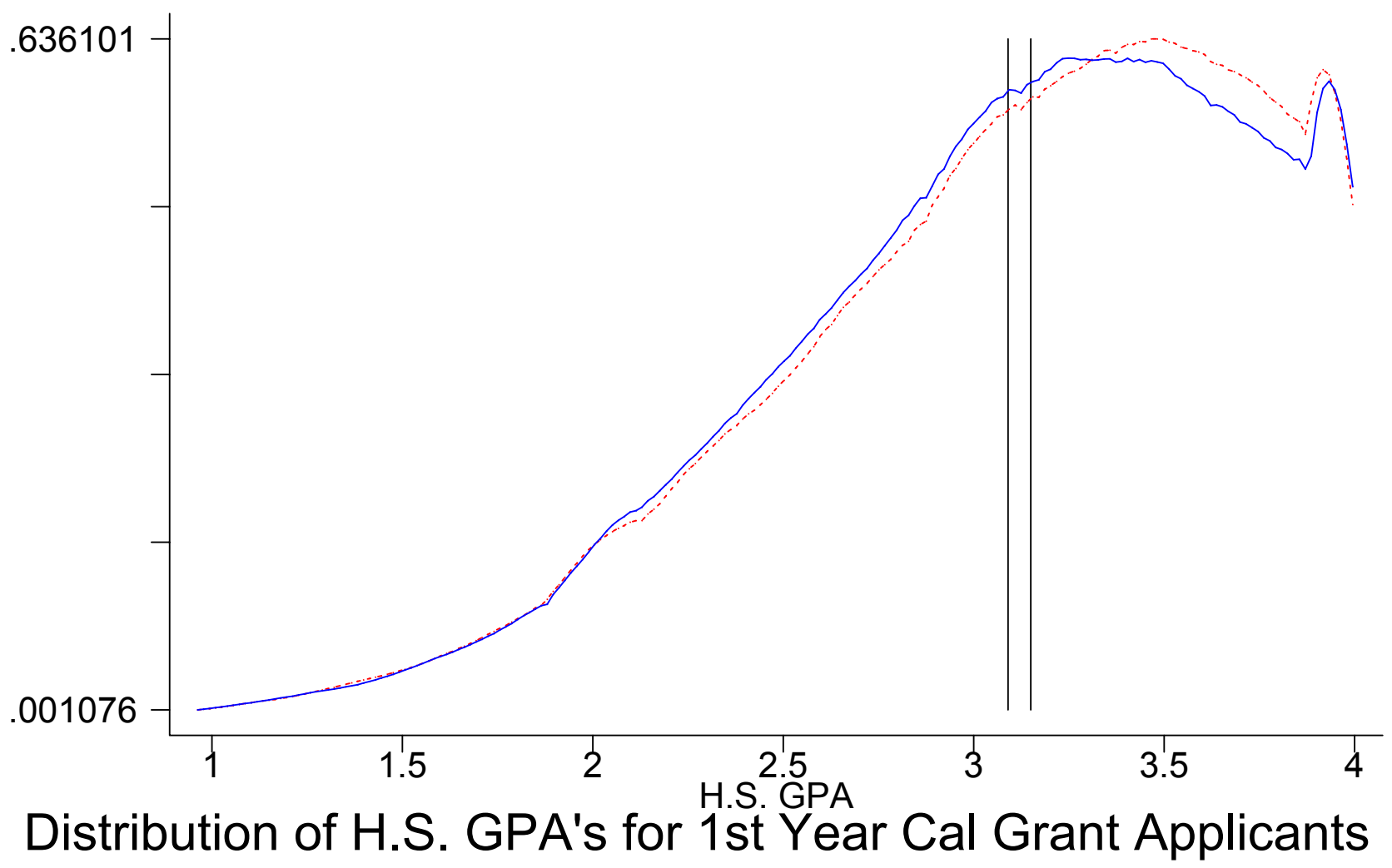


Figure 2.

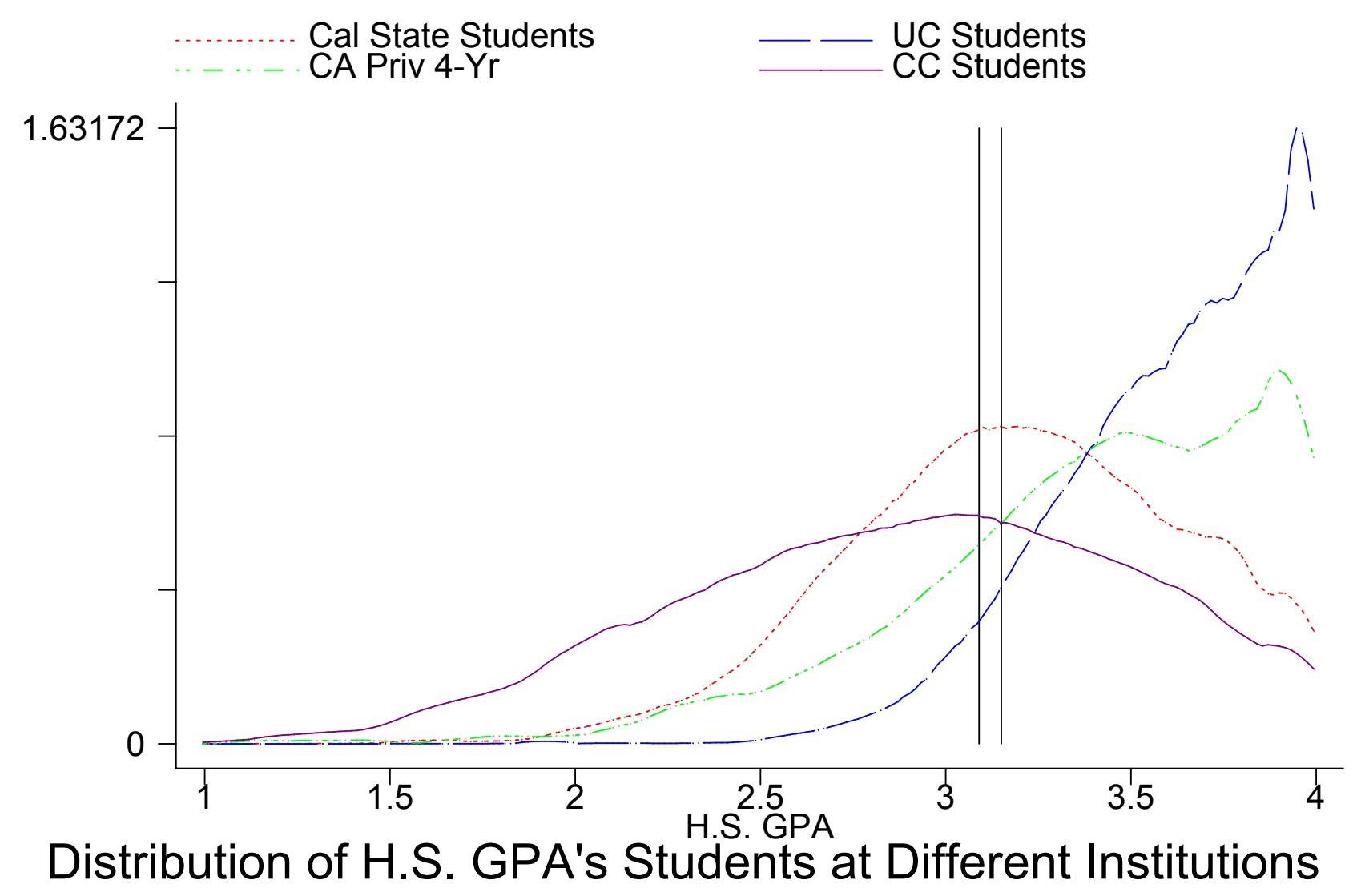


Figure 3.
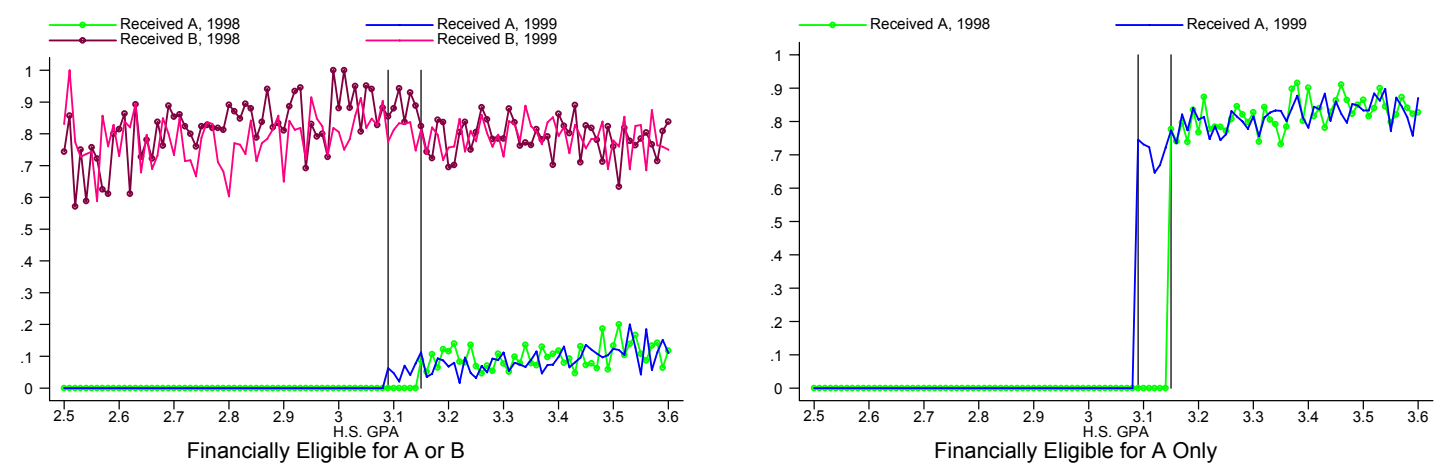

College Entrants Receiving Cal Grants by H.S. GPA 


\section{Figure 4.}


Subsample with Full NSC Coverage

Regression Discontinuity Results for 1998

Note: Actual and predicted enrollment rates are reported for .03 GPA point categories. The categories are graphed by the value of GPA at the beginning of the interval. 
Figure 5.
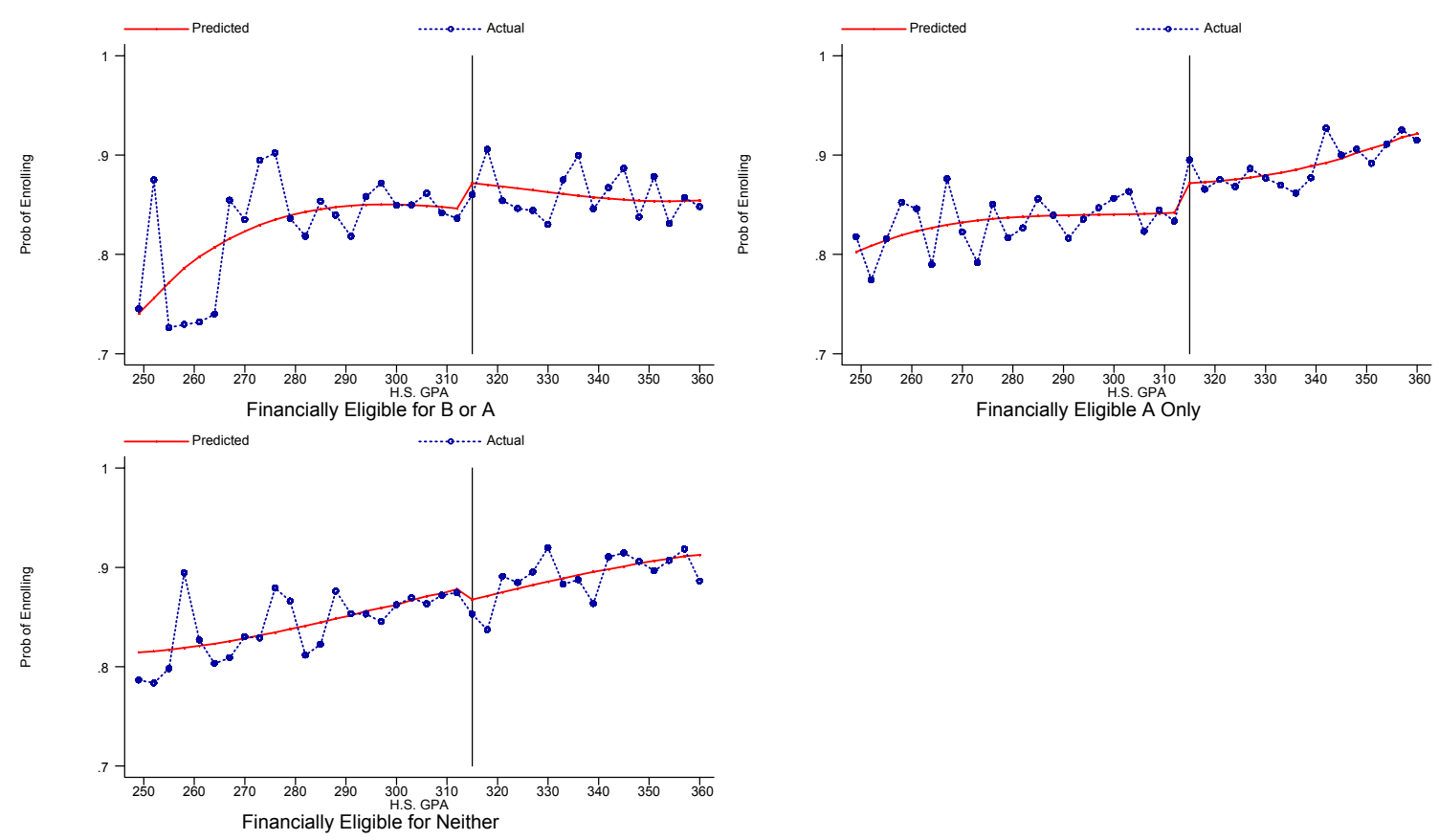

Full Sample

Regression Discontinuity Results for 1998

Note: Actual and predicted enrollment rates are reported for .03 GPA point categories. The categories are graphed by the value of GPA at the beginning of the interval. 
Figure 6.

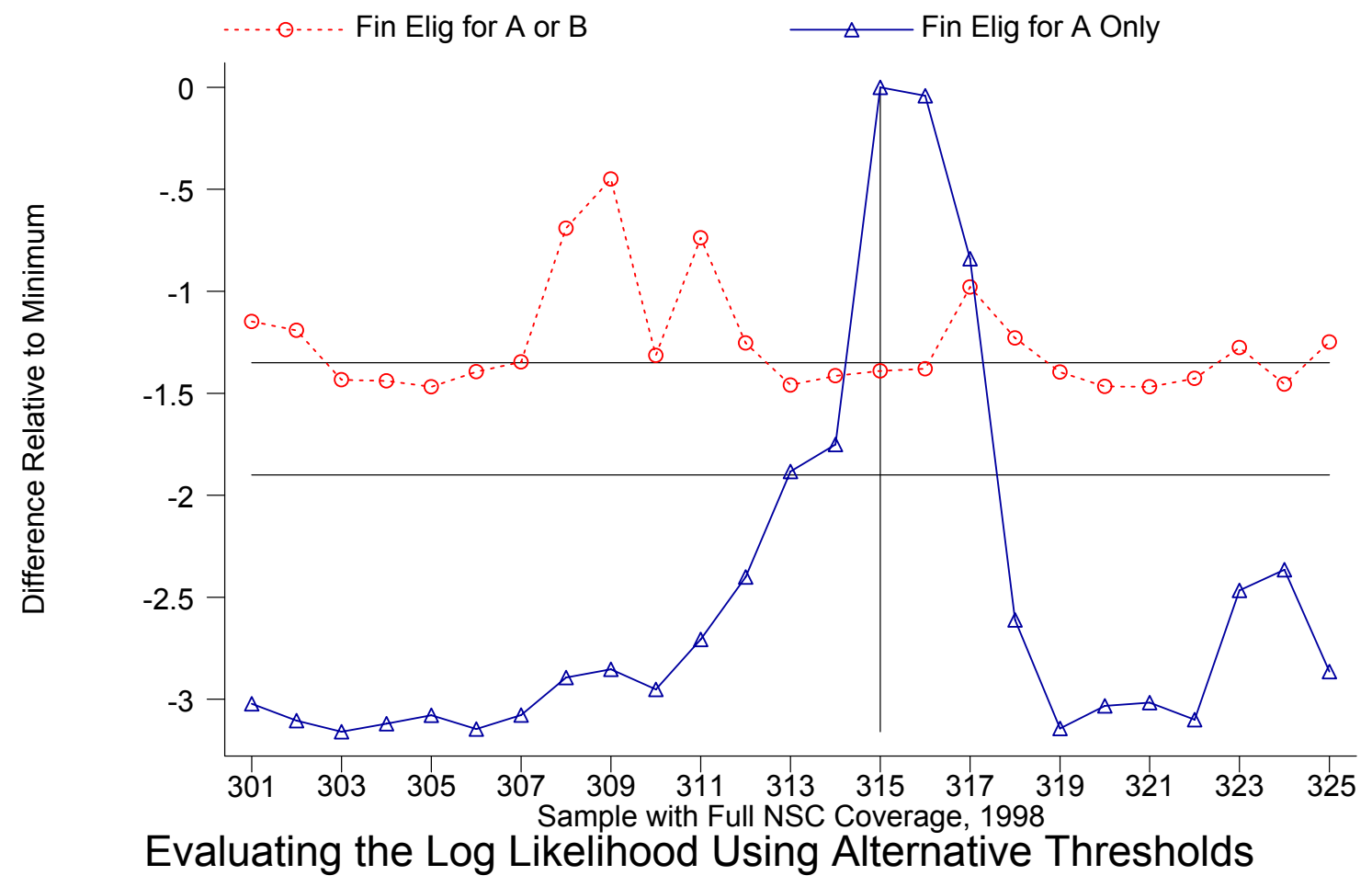


Figure 7.

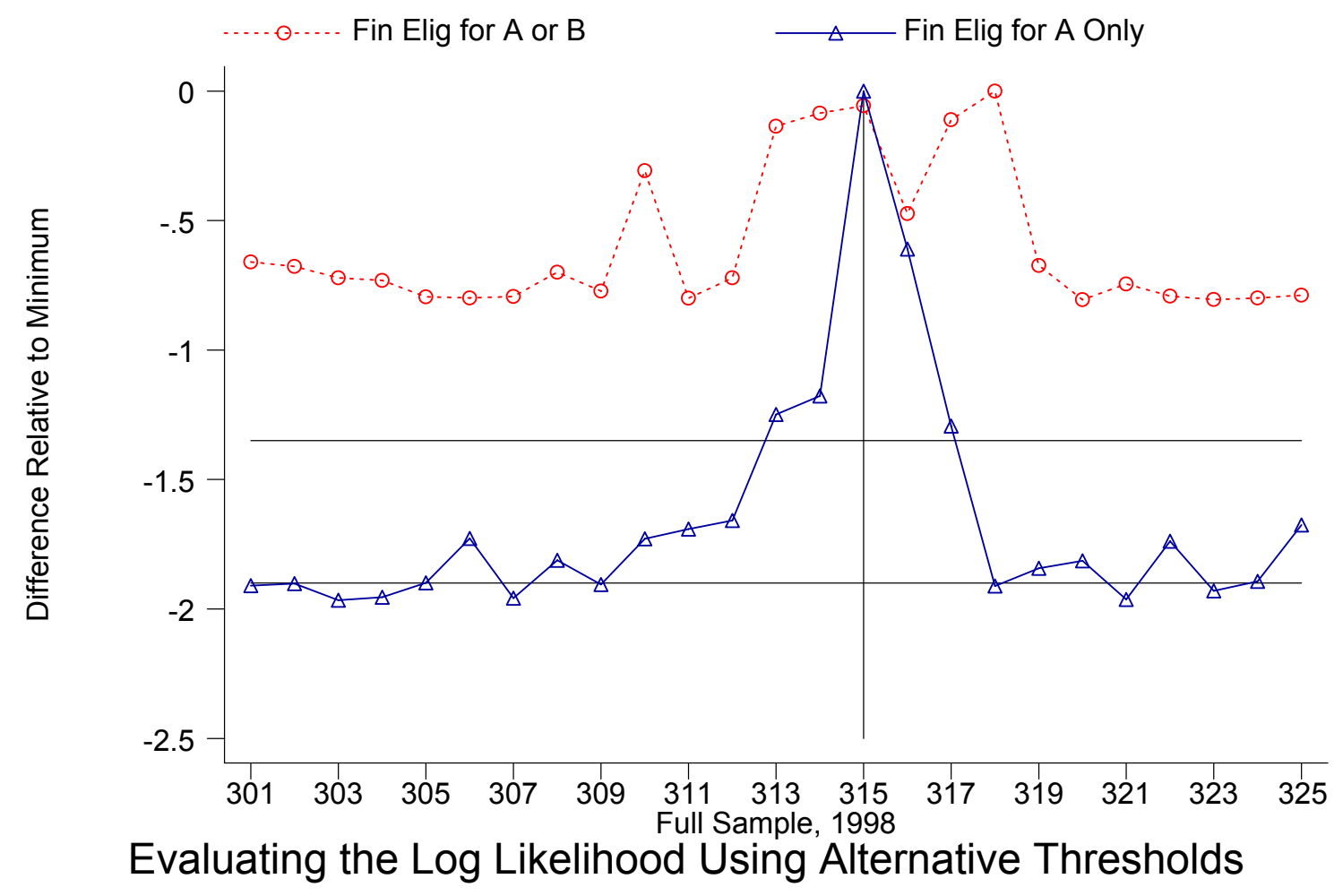


Figure 8.
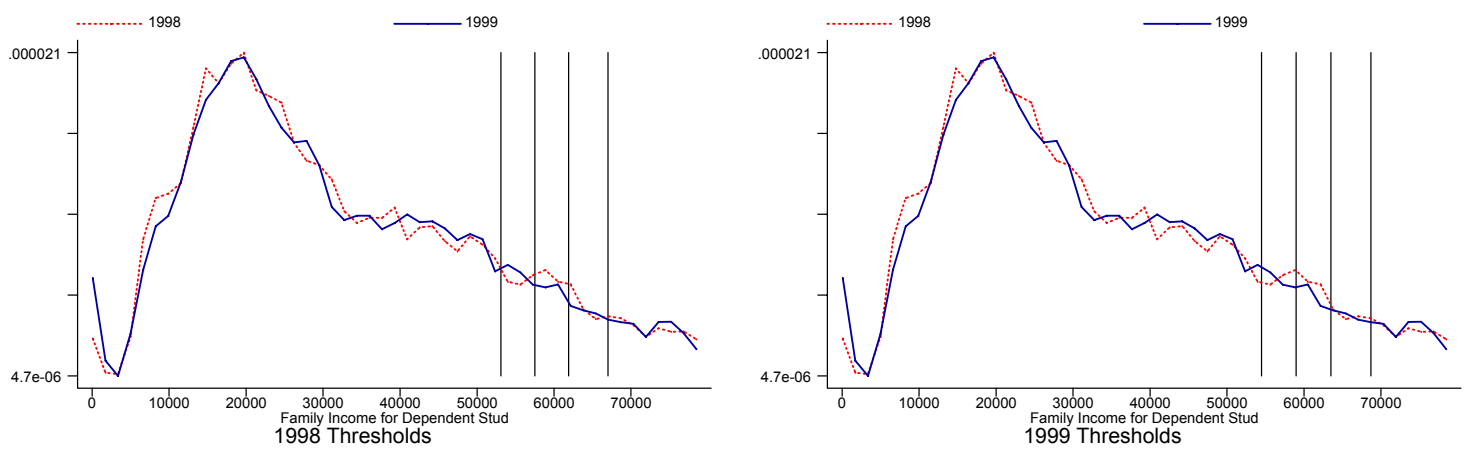

Income Distribution for GPA and Asset Elig Students 


\section{Figure 9.}
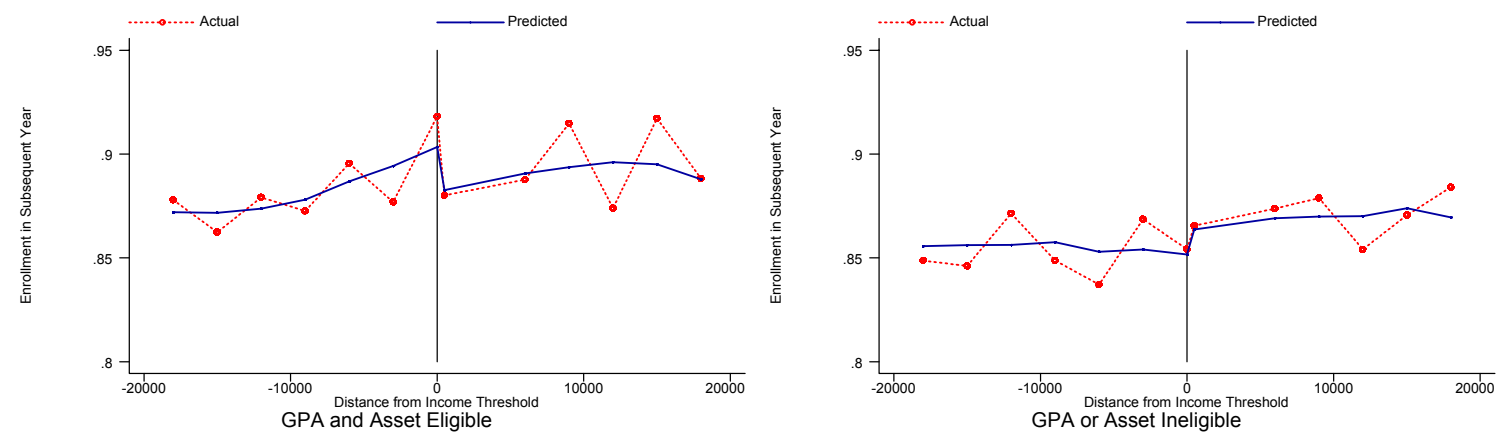

Sample with Full NSC Coverage

Regression Discontinuity Results using Income Thresholds

Note: Actual and predicted enrollment rates are reported for intervals of $\$ 3,000$ from 0 . Enrollment rates are plotted by the value of income at the end of the interval closest to zero. 
Figure 10.




Figure 11.

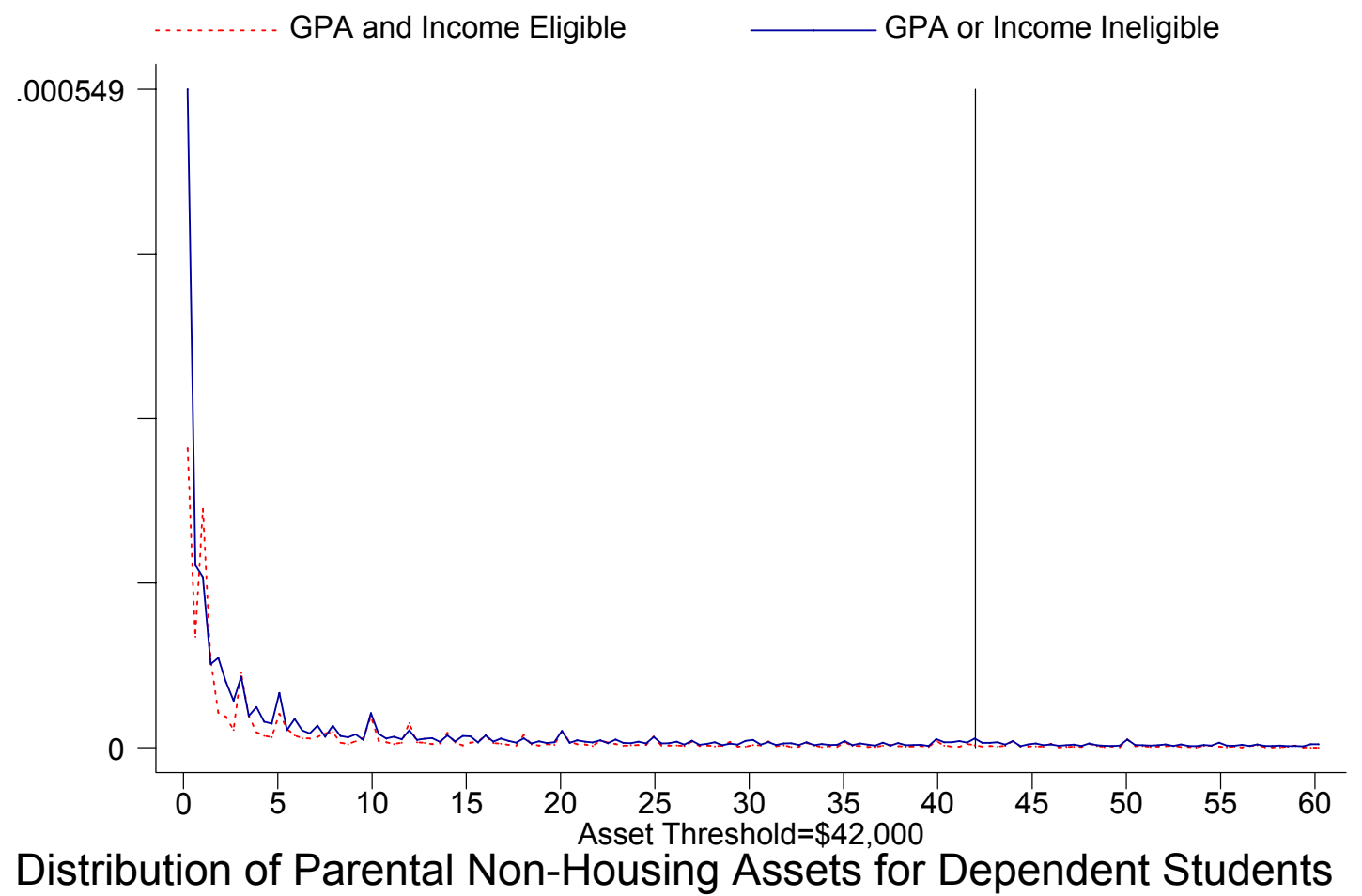


Figure 12.
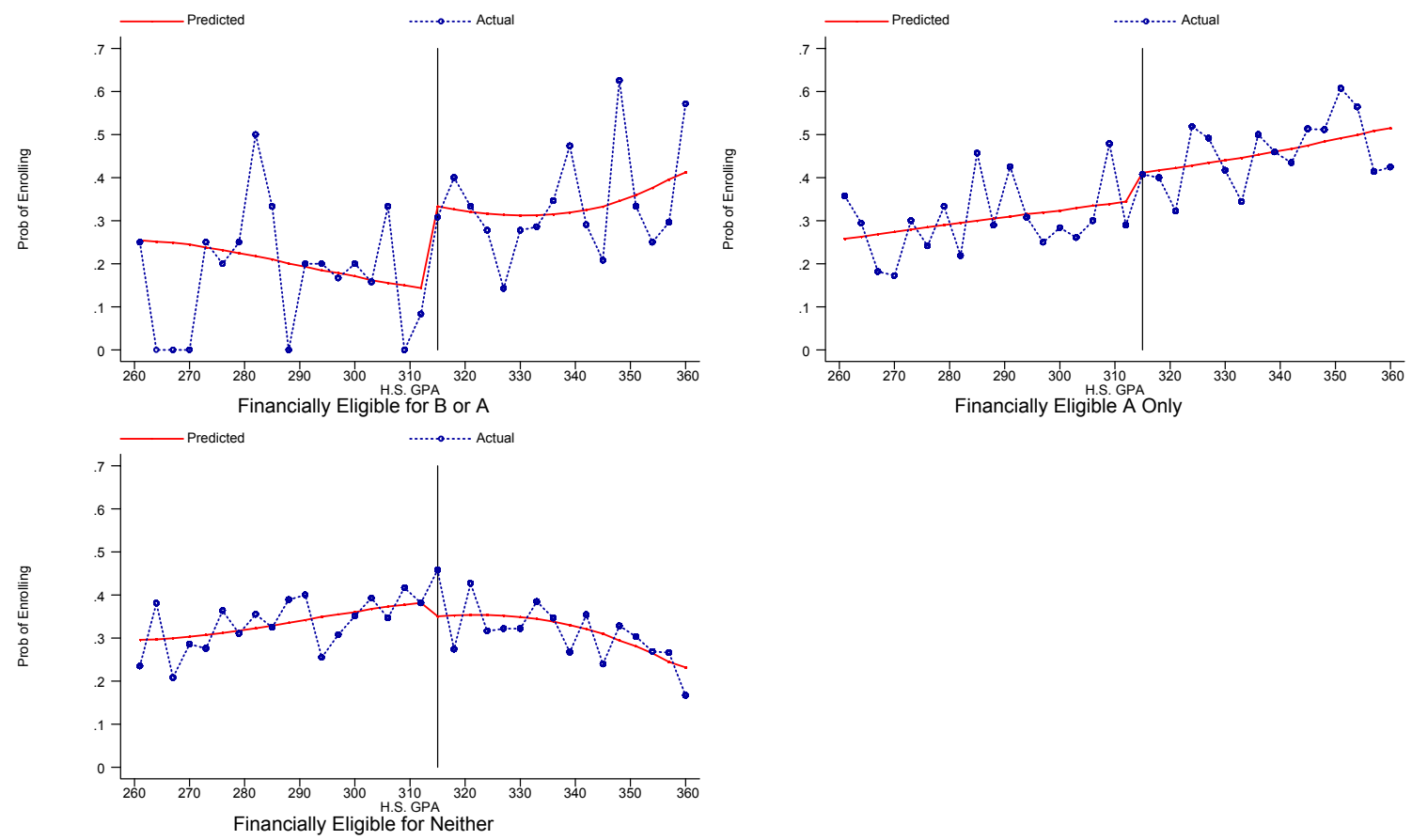

Full NSC Cover, Applied 4 Yr Priv in CA Prob of Attending a 4 Yr Priv in CA

Note: Actual and predicted enrollment rates are reported for $\mathbf{0 3}$ GPA point categories. The categories are graphed by the value of GPA at the beginning of the interval. 


\section{Figure 13.}
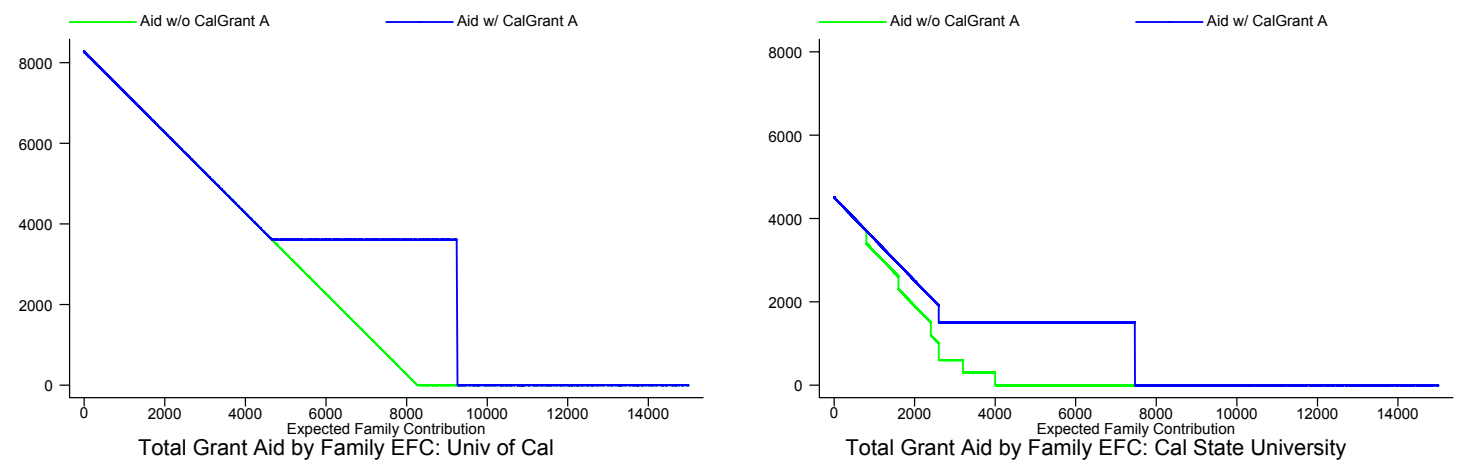

Crowd Out of Institutional Grant Aid 